\title{
Second survey of heterobranch sea slugs (Mollusca, Gastropoda, Heterobranchia) from Bunaken National Park, North Sulawesi, Indonesia - how much do we know after 12 years?
}

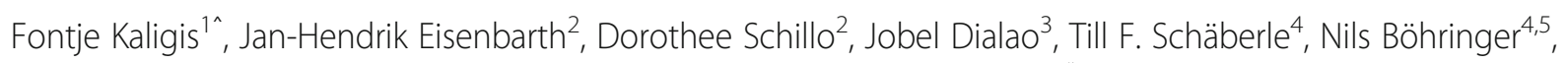
Robert Bara ${ }^{1}$, Sven Reumschüssel ${ }^{3}$, Gabriele M. König ${ }^{5}$ and Heike Wägele $2^{2^{*}}$

\begin{abstract}
Background: Bunaken National Park (BNP) is one of the most famous marine national parks in Indonesia with an extraordinary diversity in marine life forms. However, this diversity is threatened by an increasing population on the islands, ongoing destructive fishing techniques and lately by an increase in tourism. Protecting and managing the future use of BNP resources will require the assessment of both, local marine biodiversity through monitoring efforts and the identification and subsequent reduction of any threats or changes in the park. A high diversity in marine Heterobranchia indicates a high diversity of metazoan life forms and a diverse habitat structure. Surveying the complete biological diversity across taxonomic groups found in BNP would be an extensive undertaking, so focus on heterobranch diversity as an indicator of coral reef health was initiated and a model group on which future monitoring and conservation efforts can be based is provided. This study follows up the first investigation of marine Heterobranchia in BNP, conducted 12 years ago, while assessing molluscan diversity, and intends to present a base line for future monitoring programs.
\end{abstract}

Results: The diversity of marine heterobranchs around BNP was surveyed with an emphasis on Bunaken Island by diving and snorkeling at nearly 20 sites. Species are listed with photographic documentation (81 species) and results compared with the former study on molluscan species diversity in BNP. Taking these two studies into account 135 species are now recorded from BNP. The low overlap of described species (21) between the two BNP studies illustrates the gap of knowledge about overall species diversity in this particular area. A comparison with other studies from the region and Indo-Pacific also provides evidence for undersampling, but show similar taxa composition except of a somewhat higher cladobranch number in relation to Anthobranchia.

Conclusions: BNP is still under-sampled with regard to sea slug diversity. Thus conclusions as to whether or not a shift in species has occurred during the 12 years since the first study cannot be drawn. More and extensive studies are necessary to completely document the species richness in this area.

Keywords: Biodiversity, Bunaken national park, Diving, Heterobranchia, Indonesia, Monitoring, "Opisthobranchs", Tourism

\footnotetext{
* Correspondence: h.waegele@leibniz-zfmk.de

Deceased

${ }^{2}$ Centre of Molecular Biodiversity, Zoological Research Museum Alexander

Koenig, Bonn, Germany

Full list of author information is available at the end of the article
} 


\section{Background}

Indonesia has the largest number of islands worldwide and a coastline of nearly $100,000 \mathrm{~km}$ in length (http://big.go.id/berita-surta/show/pentingnya-informasi-geospasial-untuk-menata-laut-indonesia). Mainly fringed by coral reefs, sea grass beds, and mangroves, its waters contain a wealth of marine species diversity that is highly threatened by many local to global factors, including climate change, raising land use and increased tourism, which have a direct local impact. This was shown recently for the Bunaken National Park (BNP) in North Sulawesi by Kholil \& Sulistyadi (2017), who suggested a limitation for visitors and higher entrance fees for BNP. In contrast, Pangemanan et al. (2012) concluded that tourism can be increased at a specific locality within Bunaken National Park (BNP); however, these authors mainly considered human related factors, like spatial area of visitors, numbers of visitors, and time while snorkeling or diving, in relation to low or high entrance fees, but not the impact tourists have on the environment. The potential damage to an environment, irrespective of the cause, can only be assessed when species diversity is documented in the first place and occurring shifts of diversity is monitored on a regular basis. This was demonstrated recently by Nimbs et al. (2016), who documented an increased number of heterobranch sea slugs from warmer seas on the eastern coast of Australia. The authors concluded that this is a consequence of climate change, based on thorough surveys of heterobranchs formerly conducted in this particular region (Nimbs \& Smith, 2016).

The marine biodiversity of Indonesia is partly documented in local journals (e.g., Maabuat et al., 2012; Setiawan et al., 2013; Ruga et al., 2014; Hurtado et al., 2014; and literature herein). More information for a wider audience is often included in text or identification books (e.g., Gosliner et al., 1996). These books or texts usually comprise the most common species. Some literature focuses on specific taxa, e.g., on fish species (Allen \& Erdmann, 2012), on soft corals (Fabricius \& Alderslade, 2001), or on molluscs (Dharma, 2005). Information on marine heterobranch diversity in Indonesia is scattered throughout books (e.g., Debelius \& Kuiter, 2007; Gosliner et al., 2008; Gosliner et al., 2015); however, a few comprehensive studies on specific areas in Indonesia indicate high species diversity (Tonozuka, 2003; Yonow, 2001, 2011, 2017).

The presence of a certain diversity of marine heterobranchs gives evidence for the overall biodiversity and health of a coral reef. Many of these sea slugs are stenophagous and feed exclusively on certain members of specific marine phyla like, among others, Porifera, various groups of Cnidaria, Ascidiacea, and Bryozoa as well as certain algae or sea grass species. Therefore, the presence of a wide range of marine heterobranchs implies a high biodiversity of many other metazoan and plant taxa within a particular coral reef and allows an assessment with regard to the conditions of the respective habitat.

Bunaken National Park is famous for its high diversity in habitat structure. Within few meters deep canyons with cave like structures (e.g., Cela Cela) alternate with coral rubble slopes. Terrace-like structures (e.g., Mamaling) can alternate with drop offs down to $50 \mathrm{~m}$ and more (Lekuan 2). The north of Bunaken Island and Manado Tua face open ocean environment with strong currents, whereas the south coast of Bunaken is more sheltered and highly influenced by (probably nutritionally higher) water masses coming from Manado shore lines during high tides. These highly diverse habitats additionally increase the species diversity, a phenomenon which is without question highly attractive for divers. Therefore, studies on BNP, which is highly exposed to local stress factors, including increasing tourism and destructive fishing methods, are essential in understanding the flexibility and endurance of this ecosystem (see Huang et al., 2015). Molluscan diversity around BNP was investigated for the first time in 2003, the results from which were published in 2006 (Burghardt et al., 2006). Three hundred twenty-three species were recorded within 10 days and nearly 80 species represented marine Heterobranchia. In addition, this former investigation includes also some Acochlidida, which live in sediments and thus are more cryptic, or live in the pelagic zone (Pteropoda).

Here, a second survey on marine Heterobranchia around BNP is presented and compared with the only other study of that area, as well as the few other studies on Indonesian marine heterobranchs. This investigation will be a start of a regular monitoring program of sea slugs in BNP, a protected area that on one hand is highly effected by anthropogenic use (local people as well as tourists), on the other hand has not suffered yet from strong El Niños with extensive coral bleaching, as can be observed in many other reefs worldwide (e.g., McClanahan \& Muthiga, 2014; Hoeksema \& Matthews, 2011; De'ath et al., 2012).

\section{Methods}

The expedition took place in August 2015. Collecting areas are outlined in Fig. 1. Eighteen dives with 3-5 divers were involved. Each dive usually lasted $60 \mathrm{~min}$, with a few exceptions of up to $120 \mathrm{~min}$. The total amount of underwater searching time was approximately 100 to 120 h. Prior experience in searching and collecting sea slugs under water varied between the divers from extremely high (one diver with daily experience for several years) to medium (two divers) and marginal experience (two divers). 


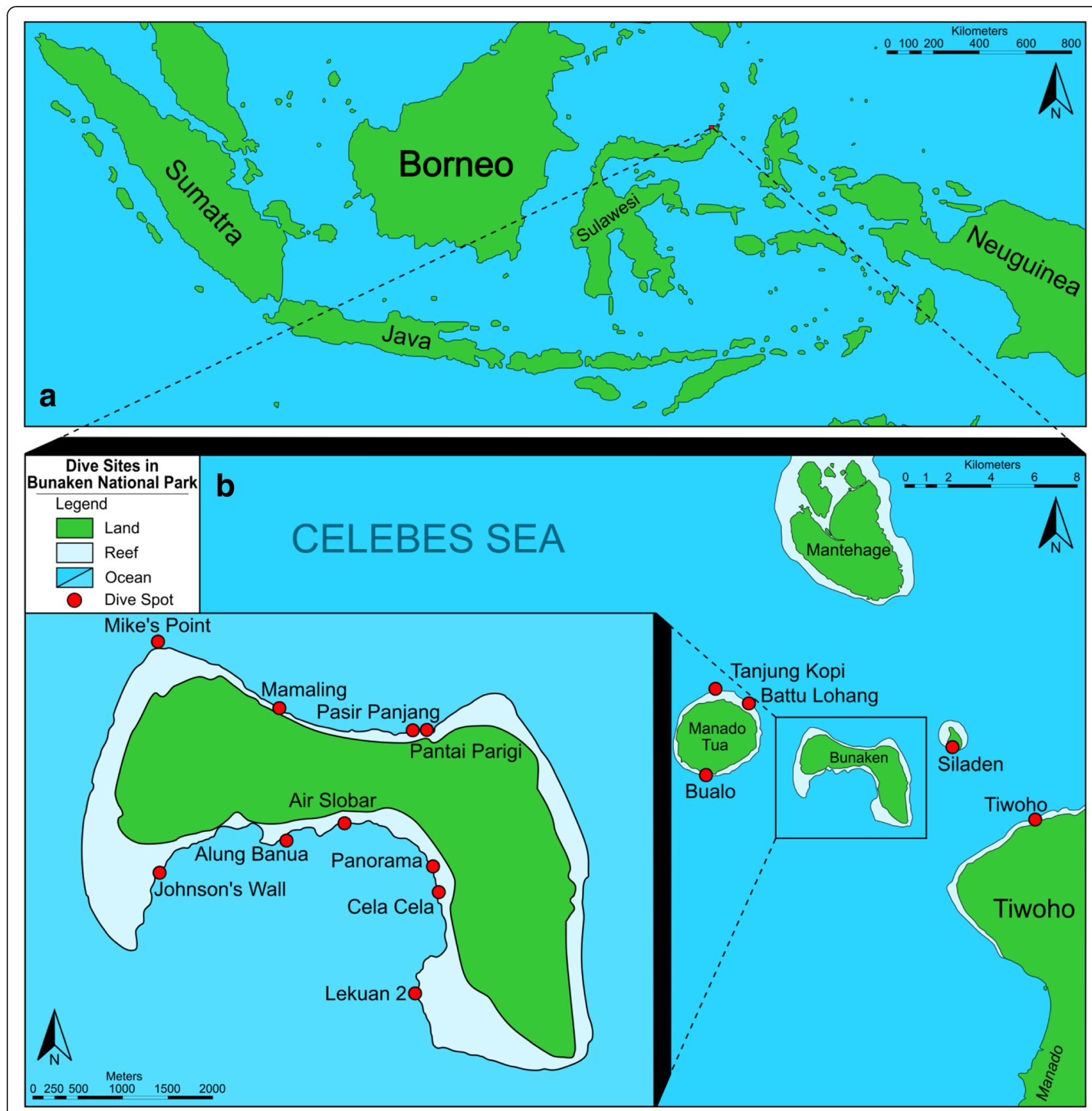

Fig. 1 Location of study area: a Indonesia and Sulawesi with red dot and dashed lines indicating close-up area in B; b Diving sites (red dots) in Bunaken National Park (insert on the left side) and the islands visited (depicted on the right side)

Sixteen sites were visited for collecting, focusing on Bunaken Island with 11 sites, three sites around Manado Tua, one site at Siladen Island and one site opposite to Bunaken Island along the mainland of North Sulawesi (Tiwoho, see Fig. 1 and Table 1). Although some sites were revisited (e.g., during the night), the collecting areas hardly overlapped with previous visits. In total 17 dives were performed during daytime (mainly in the morning) and two dives during the night (Table 1). Additionally, several hours were spent snorkeling.
Sea slugs were always collected directly from substrate in the field by scuba diving or by snorkeling and preliminary identified by various identification books (Debelius \& Kuiter, 2007; Gosliner et al., 2008; subsequently also Gosliner et al., 2015) and scientific publications (Yonow, 2001, 2011, 2017; Martynov \& Korshunova, 2012) and additionally by the Sea Slug Forum (2017) (www.seaslugforum.net). Validity of species names was checked with the help of the World Register of Marine Species (WoRMS 2017) 
Table 1 Collection sites (dive spots) with abbreviations, as used in Table 3. Further details of localities (see also Fig. 1), including habitat structure and collecting dates are given

\begin{tabular}{|c|c|c|c|c|}
\hline $\begin{array}{l}\text { Area and name of } \\
\text { collection site }\end{array}$ & Abbreviation & $\begin{array}{l}\text { Geographic } \\
\text { location }\end{array}$ & Characterization of the habitat & Date of collection \\
\hline \multicolumn{5}{|l|}{ Bunaken South } \\
\hline Air Slobar & AS & 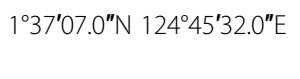 & Wall-like coral reef structure with canyons and caves & $\begin{array}{l}15 / 08 / 15 \\
25 / 08 / 15\end{array}$ \\
\hline Alung Banua & $A B$ & $1^{\circ} 36^{\prime} 60.0^{\prime \prime} \mathrm{N} 124^{\circ} 45^{\prime} 11.5^{\prime \prime} \mathrm{E}$ & Wall-like coral reef structure with canyons and caves & 23/08/15 \\
\hline Panorama & $\mathrm{Pa}$ & 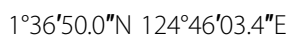 & Wall-like coral reef structure with deep canyons & 14/08/15 \\
\hline Cela Cela & CC & $1^{\circ} 36^{\prime} 42.4^{\prime \prime} \mathrm{N} 124^{\circ} 46^{\prime} 04.7^{\prime \prime} \mathrm{E}$ & Wall-like coral reef structure with deep canyons & $\begin{array}{l}\text { 13/08/15 } \\
\text { 19/08/15 (night dive) } \\
25 / 08 / 15 \text { (night dive) }\end{array}$ \\
\hline Johnson's Wall & $J W$ & $1^{\circ} 36^{\prime} 48.4^{\prime \prime} \mathrm{N} 124^{\circ} 44^{\prime} 22.8^{\prime \prime} \mathrm{E}$ & $\begin{array}{l}\text { Wall-like coral reef structure with canyons, as well } \\
\text { as coral slopes }\end{array}$ & 19/08/15 \\
\hline Lekuan 2 & Le2 & $1^{\circ} 36^{\prime} 04.4^{\prime \prime} \mathrm{N} 124^{\circ} 45^{\prime} 54.4^{\prime \prime} \mathrm{E}$ & $\begin{array}{l}\text { Coral and sand slopes with wall-like coral reef } \\
\text { structure in between }\end{array}$ & 20/08/15 \\
\hline \multicolumn{5}{|l|}{ Bunaken North } \\
\hline Mamaling & Ma & $1^{\circ} 37^{\prime} 50.6^{\prime \prime} \mathrm{N} 124^{\circ} 45^{\prime} 48.0^{\prime \prime} \mathrm{E}$ & Slope with terraces and with many tiny caves & 21/08/15 \\
\hline Mike's Point & MP & $1^{\circ} 38^{\prime} 12.6^{\prime \prime} \mathrm{N} 124^{\circ} 44^{\prime} 23.0^{\prime \prime} \mathrm{E}$ & Slope with terraces and with many tiny caves & 28/08/15 \\
\hline Pasir Panjang & PPg & $1^{\circ} 37^{\prime} 41.7^{\prime \prime} \mathrm{N} 124^{\circ} 45^{\prime} 57.0^{\prime \prime} \mathrm{E}$ & Slope with terraces and with many tiny caves & $\begin{array}{l}16 / 08 / 15 \\
26 / 08 / 15\end{array}$ \\
\hline Pantai Parigi & $\mathrm{PPi}$ & $1^{\circ} 37^{\prime} 42.0^{\prime \prime} \mathrm{N} 124^{\circ} 46^{\prime} 01.0^{\prime \prime} \mathrm{E}$ & Slope with terraces and with many tiny caves & 22/08/15 \\
\hline \multicolumn{5}{|l|}{ Manado Tua } \\
\hline Battu Lohag & BL & $1^{\circ} 38^{\prime} 46.1^{\prime \prime} \mathrm{N} 124^{\circ} 42^{\prime} 48.0^{\prime \prime} \mathrm{E}$ & $\begin{array}{l}\text { Slopes with coral rubble in the upper sublittoral } \\
\text { and wall like structures below } 6 \mathrm{~m}\end{array}$ & 24/08/15 \\
\hline Bualo & $\mathrm{Bu}$ & 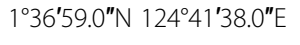 & Walls & 17/08/15 \\
\hline Tanjung Kopi & TK & $1^{\circ} 39^{\prime} 07.1^{\prime \prime} \mathrm{N} 124^{\circ} 41^{\prime} 49.6^{\prime \prime} \mathrm{E}$ & Slope until $30 \mathrm{~m}$ and then drop off (wall like) & 28/08/15 \\
\hline \multicolumn{5}{|l|}{ Siladen } \\
\hline Siladen & $\mathrm{Si}$ & $1^{\circ} 37^{\prime} 35.7^{\prime \prime} \mathrm{N} 124^{\circ} 48^{\prime} 03.6^{\prime \prime} \mathrm{E}$ & Wall with many tiny caves & 18/08/15 \\
\hline \multicolumn{5}{|l|}{ Mainland } \\
\hline Tiwoho & $\mathrm{Ti}$ & $1^{\circ} 35^{\prime} 46.8^{\prime \prime} \mathrm{N} 124^{\circ} 50^{\prime} 15.9^{\prime \prime} \mathrm{E}$ & Wall and terraces with tiny caves & 27/08/15 \\
\hline
\end{tabular}

(www.marinespecies.org) and we followed the systematics as well as genus affiliations suggested by this website.

No substrate samples (algae, sediment or coral rubble) were collected. Thus, tiny and interstitial heterobranchs are certainly missing.

All animals were recorded with metadata that will be available in the internet portal of Diversity Workbench (Triebel et al., 2017) within the module DiversityCollection (https://diversityworkbench.net/Portal/DiversityCollection). Usually, a small piece of the animals was taken and stored in $96 \% \mathrm{EtOH}$ for future barcoding. All material was collected with necessary permissions according to the Nagoya Protocol.

\section{Results}

Almost 600 specimens comprising 81 species were found and recorded in Table 3. All species are depicted in Figs. 2, 3, 4, 5, 6, 7, 8 with a specimen identifier. New species or queries are discussed in this section.

\section{Cephalaspidea (Fig. 2)}

Recently Ong et al. (2017) described several new Siphopteron species from the Philippines. Siphopteron dumbo Ong et al., 2017 seems especially similar to the two specimens found under coral rubble of Siladen Island. However, $S$. dumbo has pale blue lines on the dorsal body, parapodia and head shield, and its distribution may be restricted to Philippines and probably Japan (Ong et al., 2017). Our specimens (Fig. 2k, l) are quite similar to the species illustrated in Gosliner et al. (2015) as Siphopteron sp. 11, with reddish irregular lines on the dorsal body and parapodia, and with one of the lines running towards the tip of the flagellum. The two Siphopteron tigrinum specimens (Fig. 2h) possess the white patch in front of the flagellum, but have less distinct bluish stripes then e.g., illustrated in Gosliner et al. (2015). 

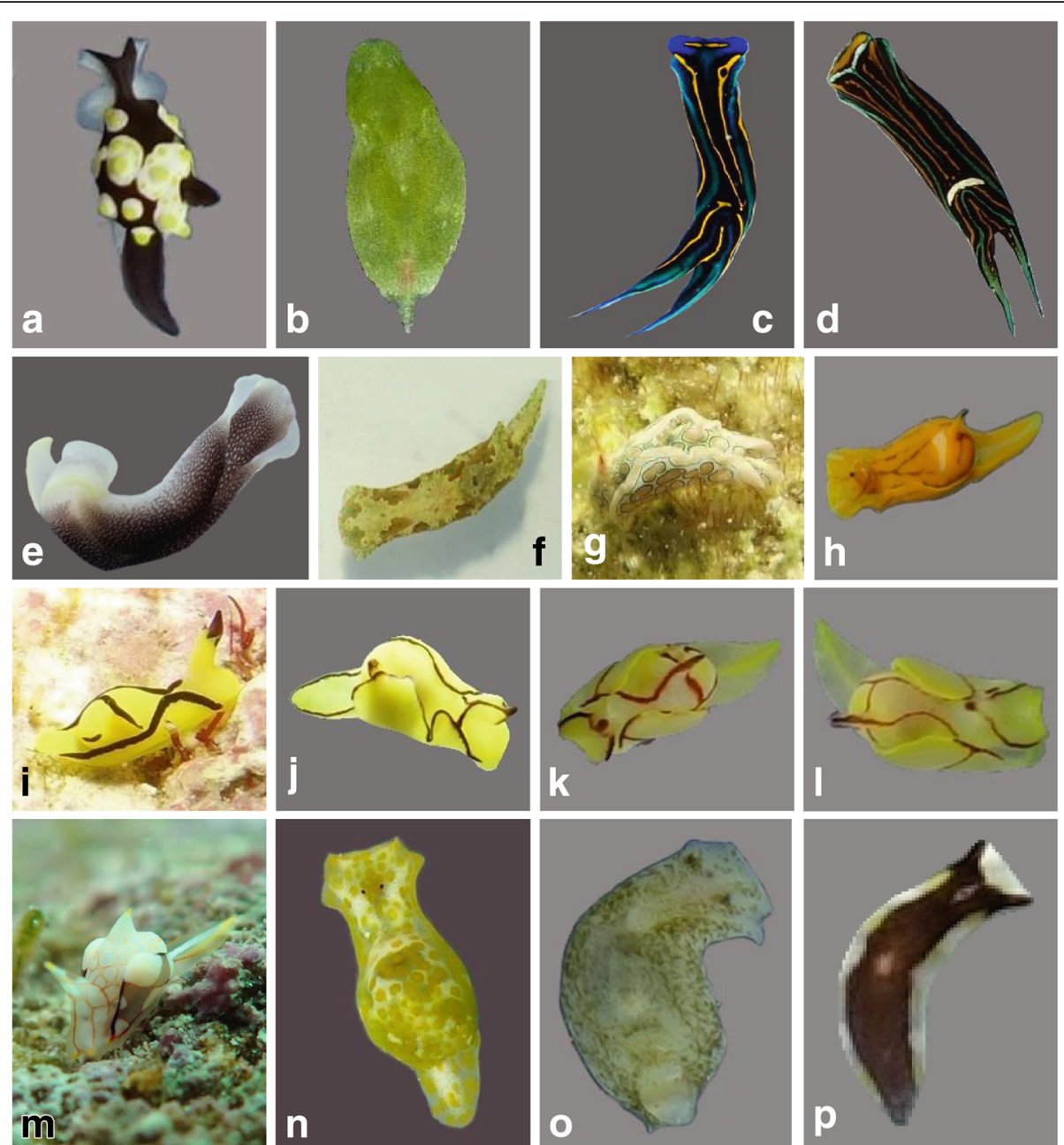

Fig. 2 Cephalaspidea \& Runcinacea: a Colpodaspis thompsoni, Coth15Bu-4; b Aglajid spec., Agsp15Bu-1; c, d Chelidonura hirundinina, Chhi15Bu-1 + 2; e Chelidonura amoena, Cham15Bu-1; f Odonotoglaja guamensis, Odgu15Bu-4; g Sagaminopteron psychedelicum, Saps15Bu-3; h Siphopteron tigrinum, Siti15Bu-1; i Siphopteron brunneomarginatum, Sibr15Bu-2; j Siphopteron nigromarginatum, Sini15Bu-15; k, I Siphopteron spec., Sini15Bu-19 + 20; m Siphopteron ladrones, Sila15Bu-1; n Haminoea spec., Hasp15Bu-4 (Haminoea sp. 2 in Gosliner et al., 2015: 30); o Haminoea spec., Hasp2_15Bu-1; p Runcina spec., Rusp15Bu-1

One Haminoea species was found (Fig. 2n), which is very similar to an animal illustrated as Haminoea sp. 2 in Gosliner et al. (2015). Another species (Fig. 20) resembles Phanerophthalmus olivaceus (depicted often as $P$. smaragdinus), but lacks the broad parapodia covering the dorsal body completely. Furthermore it did not show the elongate habitus typical for Phanerophthalmus species. Therefore we tentatively assigned it to Haminoea.

\section{Anaspidea (Fig. 3)}

Stylocheilus longicaudus and S. striatus are considered as different species by some authors (e.g., Gosliner et al., 2015 ), or only as two color variations of S. longicaudus (Yonow, 2012). Based on the overall brownish color and the blue spots, we assigned our specimen to S. striatus.

\section{Sacoglossa (Fig. 3)}

Gosliner et al. (2015) distinguish several undescribed Lobiger species from Lobiger viridis, which is distributed throughout the Indo-Pacific and exhibits blue lines on the body. One specimen (Fig. 3c) lacked these lines and resembled Lobiger sp. 1 as illustrated in Gosliner et al. (2015).

Four specimens of a tiny Cyerce species (Cyerce spec. 4) (Fig. 3e) with a length of approximately 4 to $6 \mathrm{~mm}$ showed some resemblances to Cyerce bourbonica Yonow, 2012 illustrated in Gosliner et al. (2015, p. 71); however, it lacks the orange band on the sides of the head and the distinct yellowish patches along the rim of the cerata, and the spots are greenish rather than black (Yonow, 2012). The original descriptions are based on rather large animals, so our animals might be juveniles and therefore lighter in color. Additionally an undescribed Cyerce species, not illustrated 

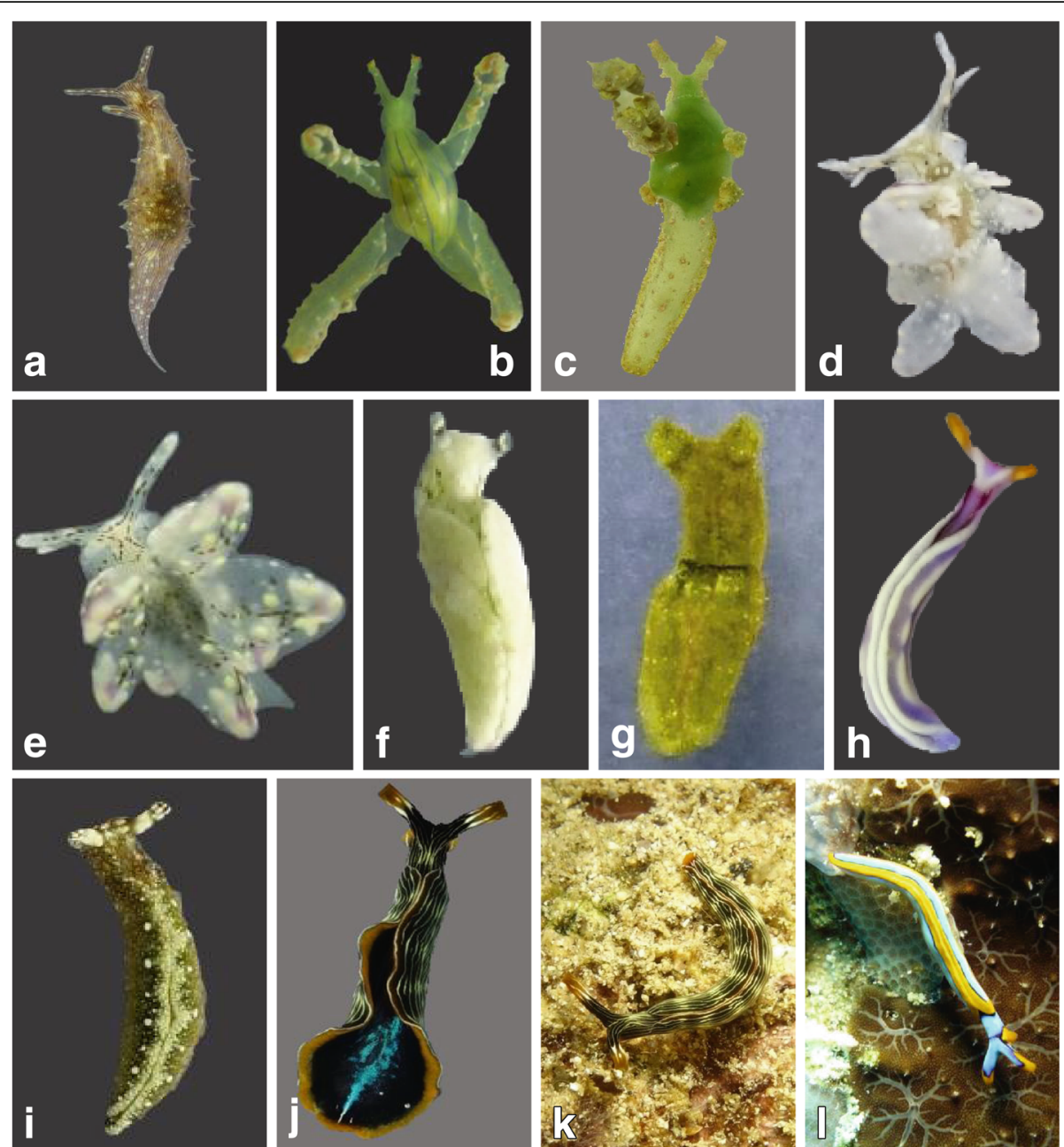

Fig. 3 Anaspidea \& Sacoglossa: a Stylocheilus striatus, Stst15Bu-1; b Lobiger viridis, Loso15Bu-1; c Lobiger spec., Lovi15Bu-1 (Lobiger sp. 1 in Gosliner et al., 2015: 70); d Cyerce spec., Cysp2_15Bu-5; e Cyerce cf. bourbonica, Cysp4_15Bu-1 (see Gosliner et al., 2015: 71); f Elysia asbecki, Elas15Bu-1; g Elysia spec., Elsp19_15Bu-2 (Elysia sp. 25 in Gosliner et al., 2015: 89); $\mathbf{h}$ Thuridilla albopustulosa, Thal15Bu-1; i Thuridilla flavomaculata, Thfl15Bu-1; j, k Thuridilla gracilis, Thgr15Bu-6; I Thuridilla lineolata, Thli15Bu-1

before, was found in similar localities as Cyerce spec. 4 (Fig. 3d).

Three specimens (Fig. 3g) similar to Elysia sp. 25 (Gosliner et al., 2015) were found in Bunaken and in Siladen Island. It has the characteristic black horizontal line on the back. Interestingly, it moves forward in a rather jerky way.

\section{Nudibranchia, Anthobranchia (Figs. 4, 5, 6, 7)}

The only Gymnodoris found during the survey (Fig. 4d) looked very similar to G. citrina; however, the row of conical tubercles along the anterior margin of the head, which is typical for this genus, could not be seen. In Gosliner et al. (2015), 59 possibly undescribed Gymnodoris species are documented; our specimen differs from all of them.
One dorid specimen with a total length of $3 \mathrm{~mm}$ was found associated with a white sponge (Fig. 5a). Although identification has to be verified, the animal looks very similar to a Rostanga specimen depicted under number 9 (Gosliner et al. 2015, p. 200) or a Hallaxa species illustrated under number 4 (Gosliner et al. 2015, p. 207).

A small dorid (Fig. 5b) was assigned to Ceratosoma sp. 1 (as illustrated in Gosliner et al., 2015). Both animals collected in Bunaken Island did not exhibit an undulating mantle edge with the rather distinct lobes next to the gills, as seems to be typical for many Ceratosoma species. Future analyses will elucidate its correct affiliation.

Chromodoris species are sometimes difficult to distinguish only by color. For example, Chromodoris lochi usually exhibits pink to yellow colored gills and rhinophores. Some specimens, Chromodoris sp. 30 (Fig. 5e) 

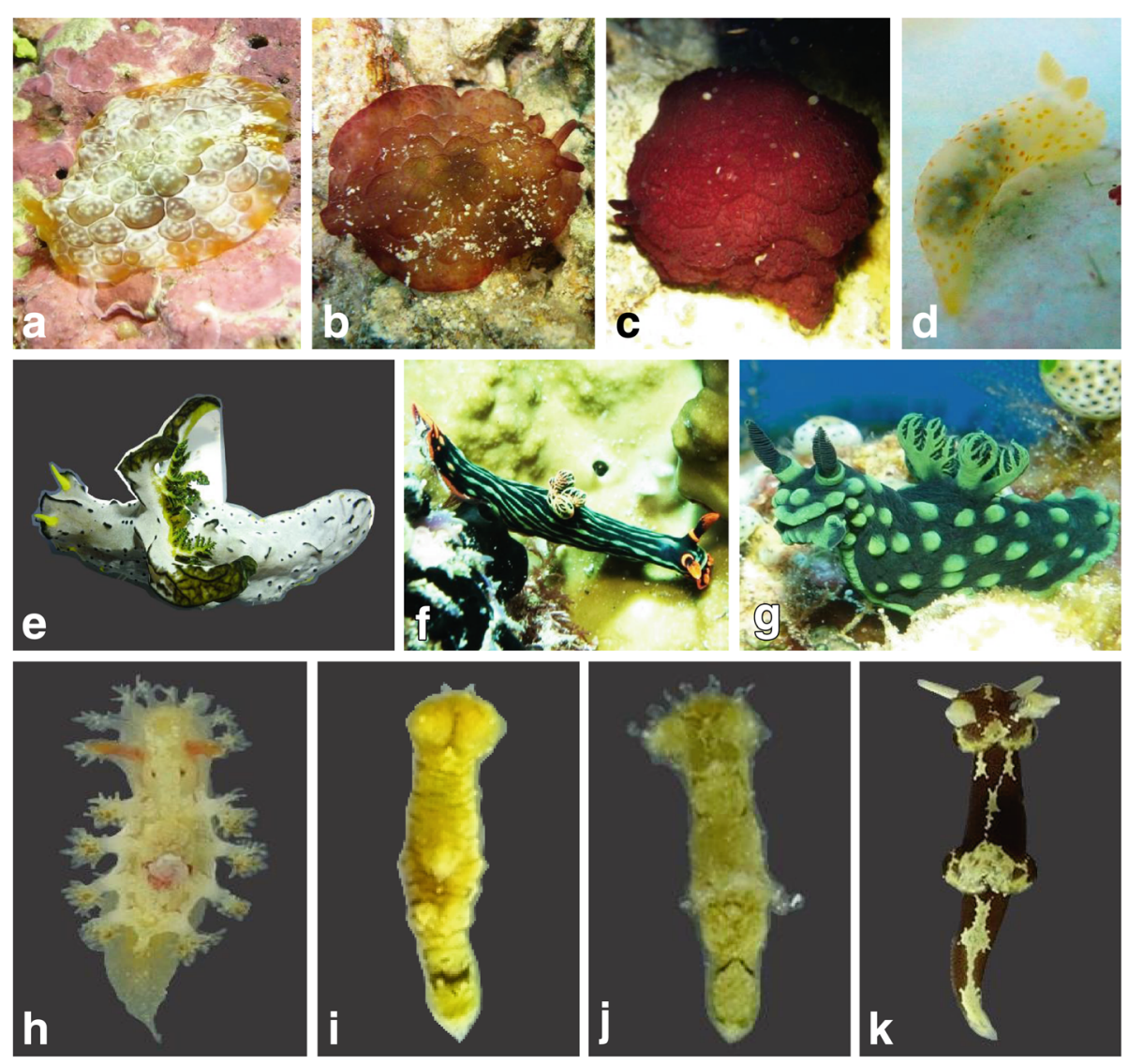

Fig. 4 Pleurobranchomorpha \& Anthobranchia: a, b, c Pleurobranchus forskalii, different color variations, Plfo15Bu-1, Plpe15Bu-2 +4; d Gymnodoris spec. Gysp1_15Bu-2; e Aegires serenae, Aese15Bu-1; f Nembrotha kubarayana, Neku15Bu-1; g Nembrotha cristata, Necr15Bu-1; h Kaloplocamus dokte, Kado15Bu-1; i Polycera risbeci, Pori15Bu-1; j Polycera japonica, Poja15Bu-1; k Trapania euryeia, Treu15Bu-1

(see Chromodoris sp. 30 in Debelius \& Kuiter, 2007, p. 176), exhibited rather dark yellow colored gills and rhinophores, thus separating them from C. lochi (Fig. 5f). Interestingly, specimens from both species were found sympatrically. However, C. sp. 30 was much more common.

Figure 5c exhibits a Chromodoris species, which shows features intermediate of $C$. lochi and C. boucheti. This animal has an additional interrupted line along the gills, which is rather typical for C. boucheti; however, it lacks the distinct black lines along the rhachis of the gills.

A large Goniobranchus specimen was found under coral rubble, which we assigned preliminarily to the species $G$. reticulatus according to Gosliner et al. (2015). Yonow (2001) pointed out that according to the original description of Quoy \& Gaimard in 1832, the foot of Goniobranchus reticulatus is patterned with red and has a yellow margin. We therefore cannot exclude that our specimen actually belongs to the species G. inopinata, which is hardly mentioned in recent identification literature.

Phyllidiella pustulosa (Fig. 7b) is a very common species that certainly needs revision. Many color variations are documented from various localities and cryptic speciation is shown in a recent molecular analysis (Stoffel et al., 2016). Some species of Phyllidiopsis are quite similar in coloration to P. pustulosa; however, the latter genus can be distinguished by the fused oral lobes (Brunckhorst, 1993).

Phyllidiopsis xishaensis (Fig. 7h) is sometimes depicted in the literature as Phyllidiopsis striata (e.g., Gosliner et al., 2015). Bergh (1889) described Phyllidiopsis striata with oral lobes similar to the genus Phyllidia, i.e., the lobes are separated. Phyllidiopsis striata was transferred to the genus Phyllidiella by Yonow et al. (2002). Our specimen has fused oral lobes and therefore can be assigned to the genus Phyllidiopsis.

Within Anthobranchia, Chromodorididae and Phyllidiidae provided the highest species numbers and also the highest specimen numbers (Table 3).

\section{Nudibranchia, Cladobranchia (Fig. 8)}

Only recently, the genus Kabeiro was distinguished from the genus Doto (Shipman \& Gosliner, 2015) by the very 

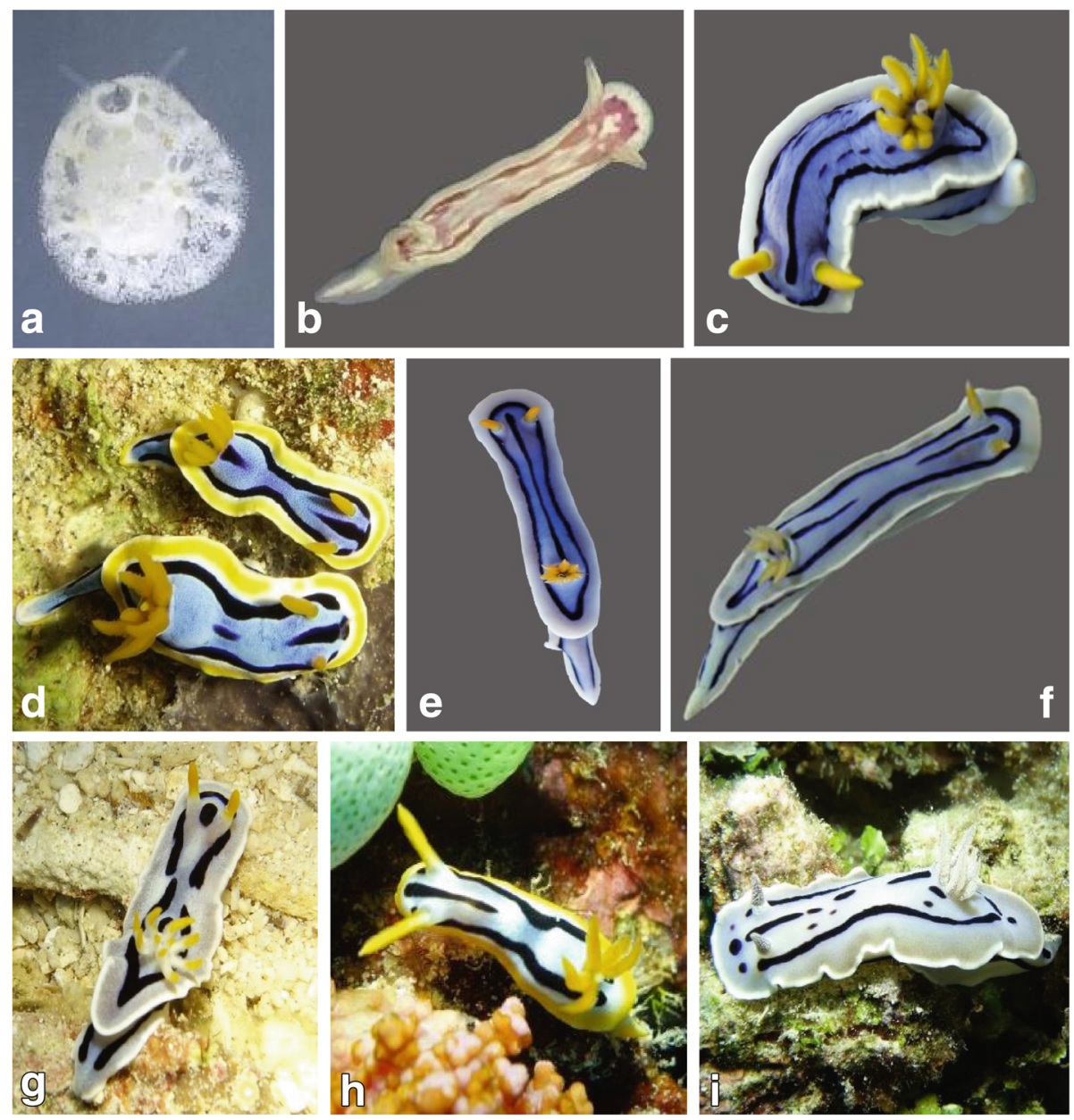

Fig. 5 Anthobranchia: a Rostanga spec., Halsp4_15Bu-1 (Rostanga sp. 9 in Gosliner et al., 2015: 200); b Ceratosoma spec., Cesp2_15Bu-3 (Ceratosoma sp. 1 in Gosliner et al., 2015: 266); c Chromodoris cf. boucheti, Chbo15Bu-1; d Chromodoris annae, Chan15Bu-8 + 9; e Chromodoris spec., Chsp30-15Bu-5 (Chromodoris sp. 30 in Debelius \& Kuiter, 2007: 176); f Chromodoris lochi, Chlo15Bu-5; g Chromodoris dianae, Chdi15Bu-13; h Chromodoris strigata, Chmi15Bu-1; i Chromodoris willani, Chwi15Bu-26

elongate body. Members of this genus usually sit on plumularid Hydrozoa. Our specimens (Fig. 8a) neither matched any depicted Kabeiro or Doto species in Gosliner et al. (2015) or any other literature records. The animals typically had globular cerata which were cream in color with dots surrounded by a thick brown ring. However, identification is very difficult due to the small size of the animals.

Gosliner et al. (2015, Dermatobranchus sp. 11) and Yonow (2017, Dermatobranchus sp. nov.) illustrate an undescribed Dermatobranchus species that most closely resemble this specimen, which we erroneously assigned first to $D$. striatus. The undescribed species, as well as our specimen (Dest15Bu-1), lack the stripes in front of the rhinophores, but show all other typical colors, especially the yellow margin of notum, foot and velum.

Gosliner et al. (2015, p. 308) illustrate two very similar Janolus species, sp. 10 and sp. 11. Our animal depicted in Fig. 8d resembles more sp. 11 because of the less narrowed cerata apices.

Korshunova et al. (2017) recently published a thorough investigation of Flabellinidae, transferring several Flabellina species into different genera and splitting the Flabellinidae in several different families. These new species affiliations apply to Flabellina exoptata (Fig. 8e) and Flabellina rubrolineata (Fig. 8g), which are now assigned to the genus Coryphellina O'Donoghue, 1929. Flabellina bicolor (Fig. 8f) is now assigned to the genus Samla Bergh, 1900. Although their phylogeny is well supported by morphological characters, we did not change the names of our collected material yet, since their phylogeny comprises mainly temperate and cold water species and inclusion of many more tropical species still might alter relationships within the aeolidacean subgroups. 

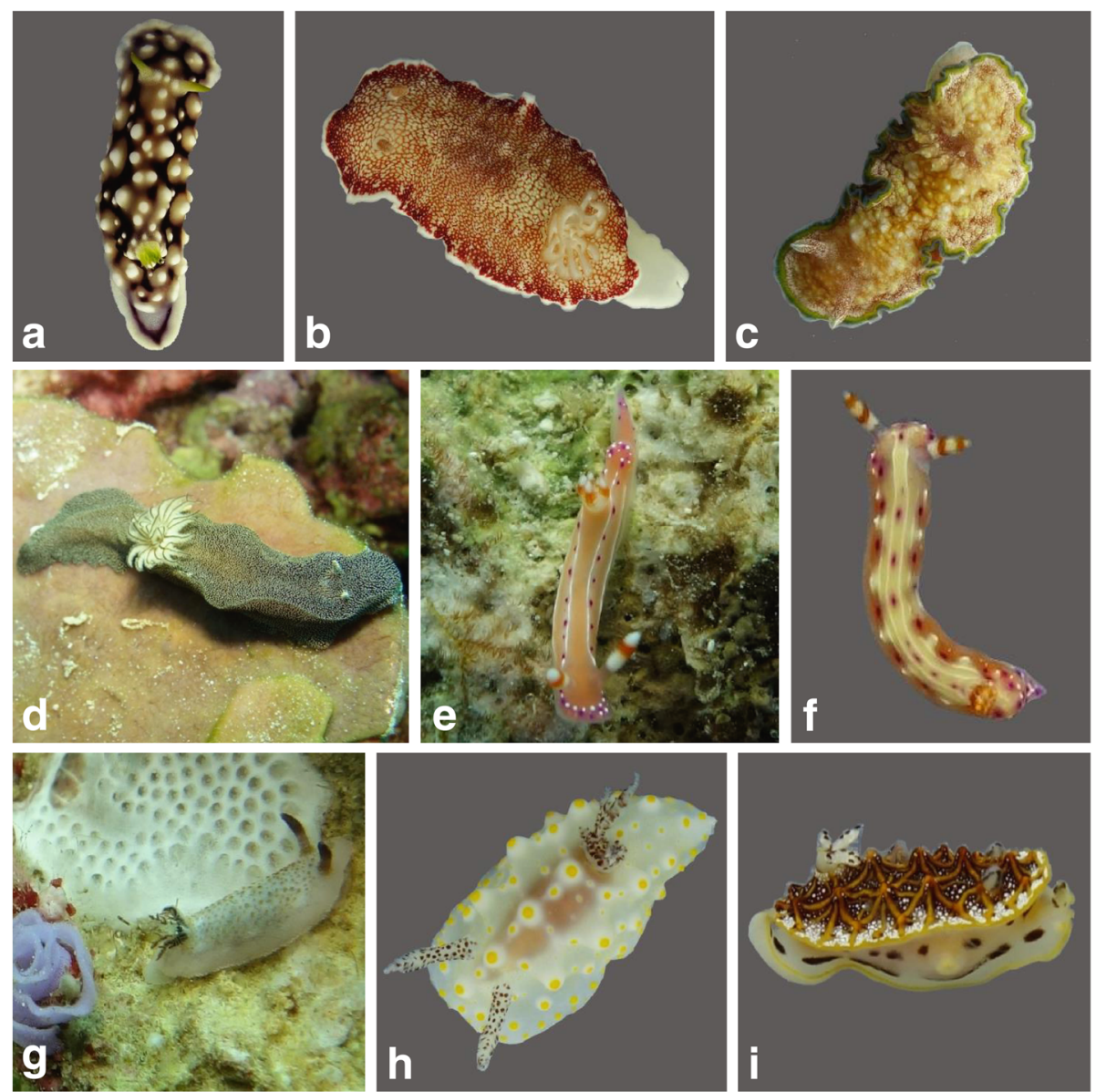

Fig. 6 Anthobranchia: a Goniobranchus geometricus, Chge15Bu-2; b Goniobranchus inopinata (or G. reticulatus), Chre15Bu-1; c Glossodoris cincta, Glci15Bu-1; d Doriprismatica stellata, Glst15Bu-2; e Thorunna australis, Thau15Bu-1; f Hypselodoris maculosa, Hyma15Bu-2; g Taringa halgerda, Taha15Bu-1; h Halgerda carlsoni, Haca15Bu-1; i Halgerda tessellata, Hate15Bu-1

Several times, a new Noumeaella species (Fig. 8j) was found crawling on the chlorophyte Caulerpa racemosa. It probably feeds on epibiontic hydrozoans.

Figures $9 \mathrm{a}$ and $\mathrm{b}$ show the marine heterobranch diversity of this study compared with the results of Burghardt et al. (2006). Overlap of described species recorded in these two studies is only 21 (15\%). Table 3 (last column) indicates those species that were found in both studies. No information can be given for the undescribed species. Summarizing data from both studies, the recorded species from BNP rises to 135 (Fig. 9b). Seventeen species from our survey have not been described yet, and some of these were never previously illustrated in literature (e.g., Noumeaella spec.).

A comparison with other biodiversity studies in Indonesia (Table 2, Fig. 10) reveal similar species numbers for Ambon (Yonow, 2001, 2011, 2017; Yonow, pers. comm.), but are lower when compared to the identification book covering mainly Bali which contains 205 species (Tonozuka, 2003). Martynov \& Korshunova (2012) recorded 151 marine heterobranchs in Vietnam, based on several years of collecting. Other studies from areas close by (e.g., Papua New Guinea) are based on even more sampling time and larger dive teams, resulting in much higher numbers (538, see Gosliner, 1992; Table 2, Fig. 10). Several other studies from limited areas in the tropical to temperate Indo-Pacific Ocean are listed in Table 2. Very often, these studies are based on long observation times including regular collections, thus resulting in higher species numbers. All studies indicate a higher presence of Anthobranchia, compared to Cladobranchia or other sea slug taxa. BNP shows a rather high number of Cladobranchia in comparison to Anthobranchia, a similar relation as is found in Papua New Guinea, but not in Ambon or Bali (Table 2).

\section{Discussion}

Our investigation aims at better understanding coral reef diversity in BNP by assessing marine heterobranch 

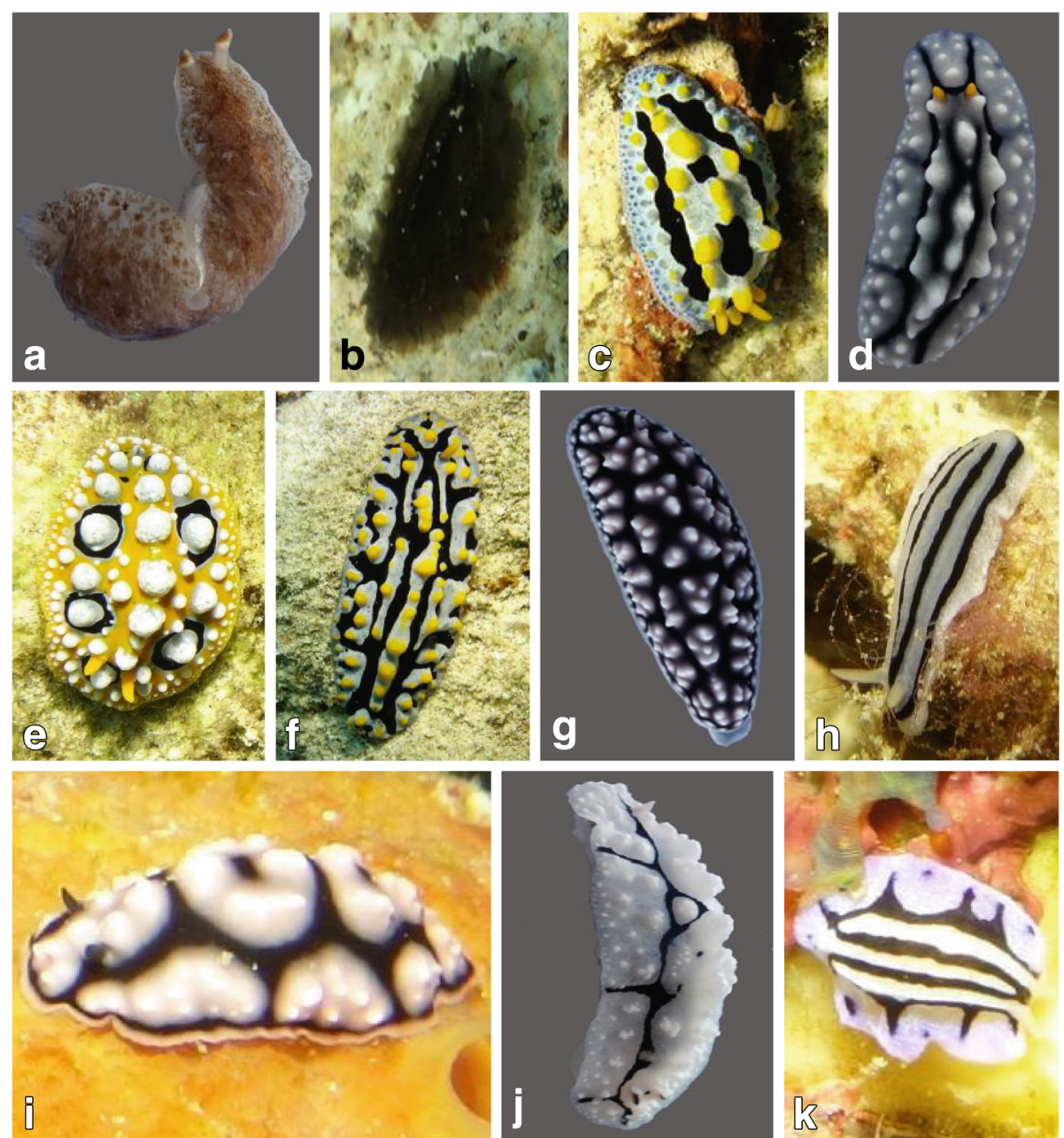

Fig. 7 Anthobranchia: a Dendrodoris albobrunnea, Defu15Bu-1; b Dendrodoris nigra, Deni15Bu-1; c Phyllidia coelestis, Phco15Bu-4; d Phyllidia elegans, Phel15Bu-4; e Phyllidia ocellata, Phoc15Bu-1; f Phyllidia varicosa, Phva15Bu-9; g Phyllidiella pustulosa, Phph15Bu-13; h Phyllidiopsis xishaensis, Phsst15Bu-1; i Phyllidiella annulata, Phan15Bu-3; j Phyllidiopsis pipeki, Phsh15Bu-1; k Phyllidiopsis sphingis, Phsph15Bu-1

species diversity in the various localities around Bunaken Island, Manado Tua, and Siladen Island, North Sulawesi, Indonesia.

Diving and snorkeling for 15 days from August 13-26, 2015 resulted in a highly diverse species composition associated with the observed diversity of habitat structure. In total, 81 species are documented here, which represent roughly $5 \%$ of the known marine heterobranch fauna from the Indo-Pacific as most recently documented by Gosliner et al. (2015).

Because collecting efforts at the various localities differed, comparing species composition and richness amongst the various collecting sites in BNP (Table 3 ) is currently not possible. However, some of the most common species, the sponge feeders Chromodoris annae (62 specimens recorded), C. dianae (64), C. willani (36), and C. sp. 30 (23) were mainly found in the southern coast line of Bunaken Island, probably due to the richness of sponges in the reef with overhanging walls, canyons and caves. Phyllidiella pustulosa (44) was common throughout all localities, whereas Phyllodesmium briareum (approximately 50) was collected from a large colony of the soft coral Briareum spec., which was found at the mainland site - an area under higher influence of river systems. Thuridilla lineolata (more than 50 specimens) was collected in larger numbers in the lower eulittoral down to $3 \mathrm{~m}$, at sites characterized by sandy areas with seagrass and few coral blocks in between, a more sheltered habitat with less wave movement behind the fringing coral reefs.

Comparing the two BNP studies from 2003 (Burghardt et al., 2006) and 2015, the number of species is quite similar (78 versus 81 ) (Fig. 9). However, the overlap of only 21 species in common (15\%) is rather low (Fig. 9). The overlap is mainly seen in common, larger species, especially from the family Chromodorididae and Phyllidiidae, or in rare species which are very conspicuous, 

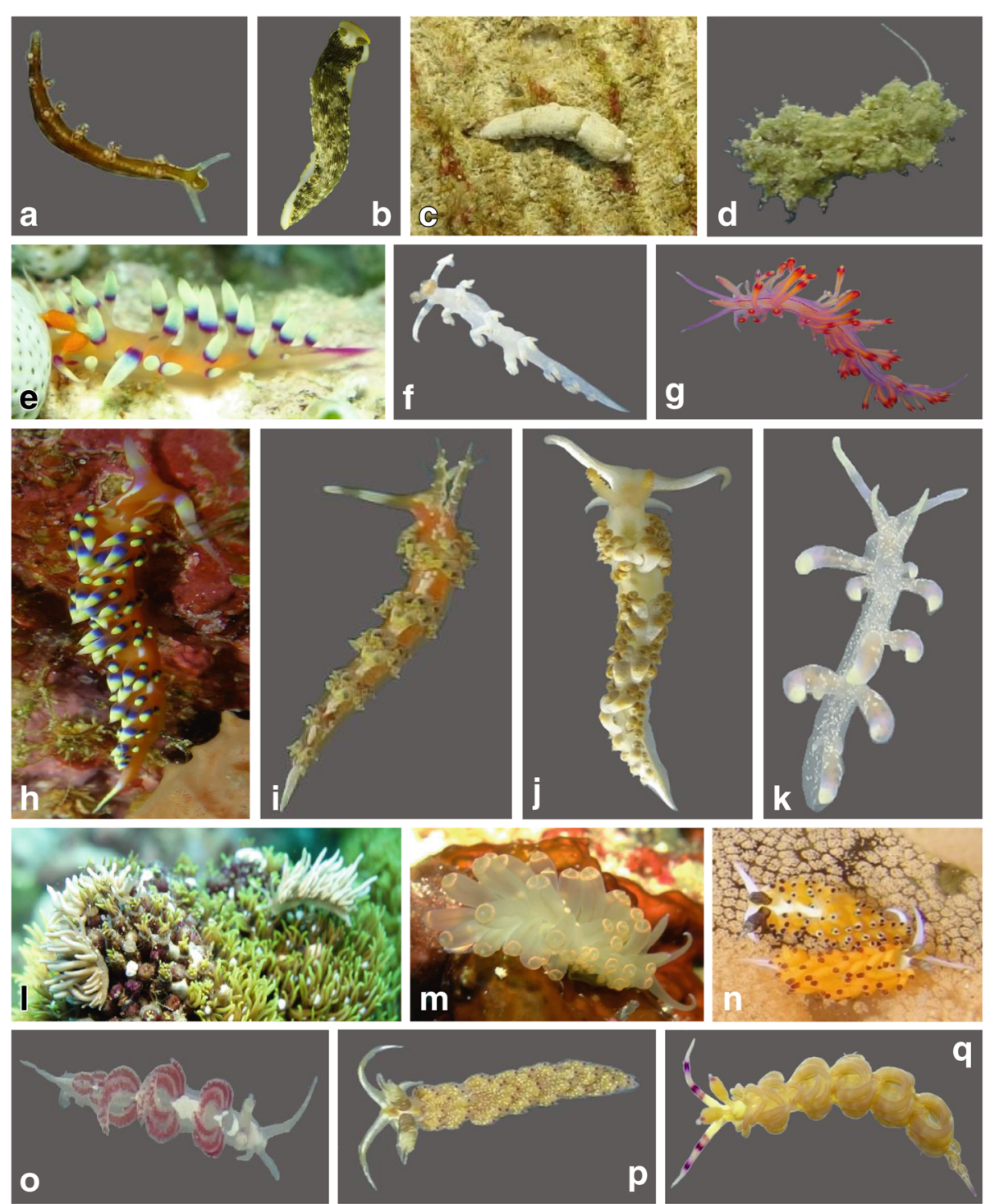

Fig. 8 Cladobranchia: a Kabeiro spec., Dotosp15Bu-1; b Dermatobranchus sp., Dest15Bu-1; c Dermatobranchus fasciatus, Desp15Bu-1; d Janolus spec., Cysp15Bu-1 (Janolus sp. 11 in Gosliner et al., 2015: 308); e Flabellina exoptata, Flex15Bu-8; f Flabellina bicolor, Flbi15Bu-1; g Flabellina rubrolineata, Flru15Bu-1; h Caloria indica, Cain15Bu-4; i Caloria spec., Casp15Bu-1 (Caloria sp. 1 in Gosliner et al., 2015: 362); j Noumeaella spec., Nosp2_15Bu 1; k Phyllodesmium poindimiei, Phypo15Bu-1; I Phyllodesmium briareum, Phbr15Bu-8 + 9; m Facelina rhodopos, Prra15Bu-1; n Favorinus tsuruganus, Fats15Bu-2; o Favorinus japonicus, Faja15Bu-1; p Favorinus mirabilis, Fami15Bu-1; q Pteraeolidia semperi, Ptse15Bu-10

like Phyllidia ocellata. Comparing sampling time, the efforts of ten days of sampling in 2003 were quite similar to this study; however, subsamples from e.g., algae or coral rubble were not analyzed in 2015 . Usually these reveal more tiny animals, which are much more difficult to collect in situ under water. Nevertheless, animals less than $5 \mathrm{~mm}$ were still recognized and collected (e.g., Colpodaspis thompsoni, Odontoglaja guamensis, Runcina spec., Rostanga spec.) especially by one of the authors (JD). The inability to recollect some species is certainly due to their cryptic appearance and might also be explained by different perceptions of the various collectors.
Considering all data from 2003 and 2015, the number of recorded species can be raised to 135 in BNP. This is an increase of more than $60 \%$ within one study. Similar effects have been published for the marine heterobranch fauna from Philippine Islands, where in total approximately 200 species were recorded initially in 1992, and continuously augmented by further collecting activities until 2014 to 1000 species (Gosliner et al., 2015).

The species diversity described here cannot easily be compared to other studies from localities in the IndoPacific Ocean, especially when species records from many years were summarized (Table 2); however other 


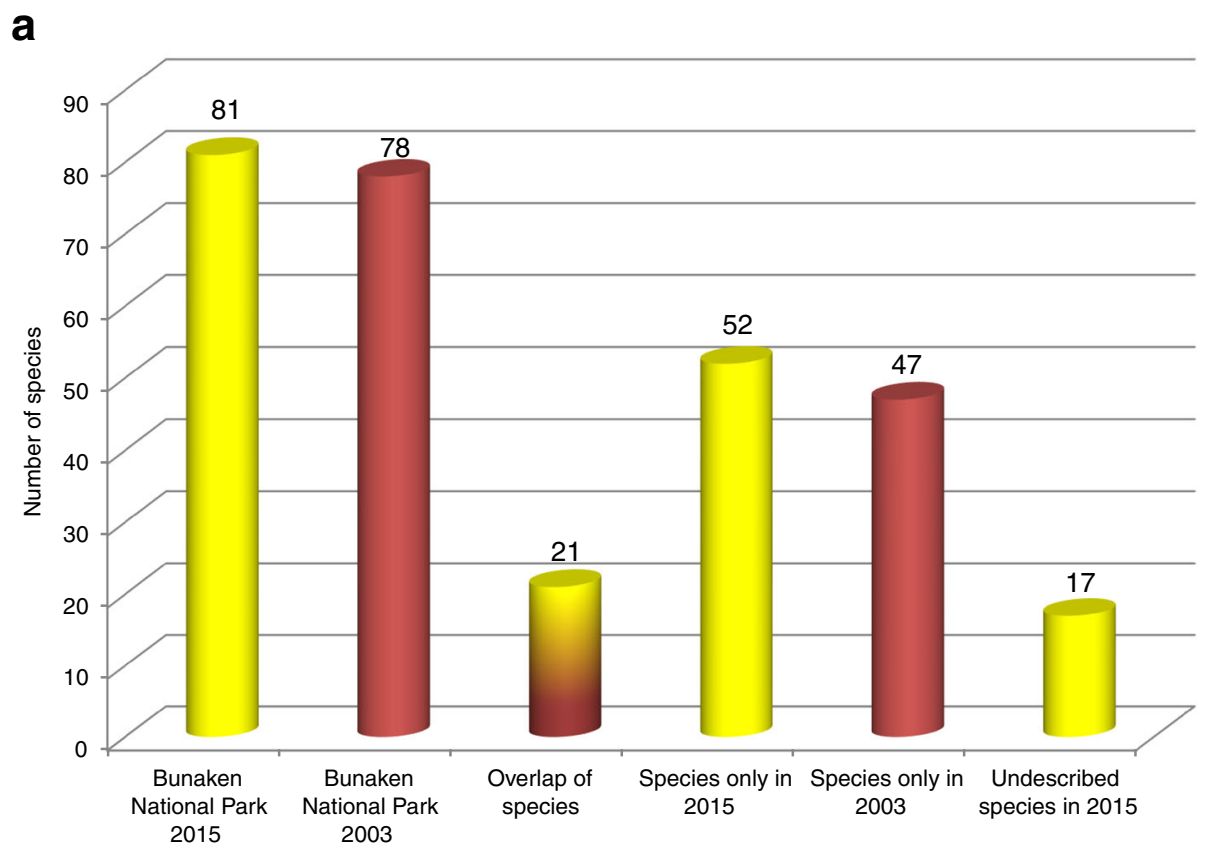

b

\begin{tabular}{|c|c|c|c|c|c|c|c|c|c|c|c|}
\hline & 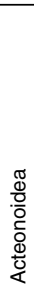 & 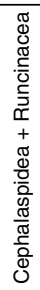 & 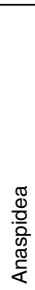 & 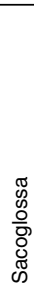 & 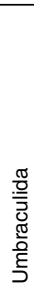 & $\begin{array}{l}\frac{\pi}{0} \\
\frac{0}{0} \\
\frac{0}{0} \\
\frac{0}{0} \\
\frac{0}{0} \\
\frac{\pi}{0} \\
\frac{\pi}{0} \\
\frac{0}{0} \\
\frac{0}{10}\end{array}$ & 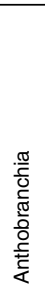 & 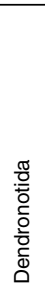 & 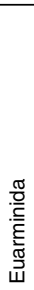 & $\begin{array}{l}\frac{\pi}{0} \\
\frac{0}{0} \overline{0} \\
\\
\end{array}$ & 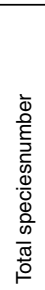 \\
\hline $\begin{array}{l}\text { Bunaken National Park } 2015 \\
\text { (this study) }\end{array}$ & 0 & 14 & 1 & 10 & 0 & 1 & 38 & 1 & 3 & 13 & 81 \\
\hline $\begin{array}{l}\text { Bunaken National Park } 2003 \\
\text { (Burghardt et al., 2006) }\end{array}$ & 0 & 17 & 4 & 8 & 0 & 3 & 33 & 1 & 2 & 10 & 78 \\
\hline $\begin{array}{l}\text { BNP: Bothstudiescombined } \\
\text { (this study) }\end{array}$ & 0 & 26 & 4 & 15 & 0 & 4 & 59 & 2 & 5 & 20 & 135 \\
\hline
\end{tabular}

Fig. 9 Comparison of species diversity in this study with Burghardt et al., 2006: a Note that the overlap of species in these two studies (with a total of 135 species) is only 23 species. The last column represents the number of species which are undescribed. $\mathbf{b}$ summarizes species composition on higher taxa level in a table

surveys can be used to gain an impression of the potential species richness and composition in BNP. When comparing species diversity on higher taxon level, both BNP surveys reflect similar relative abundances of Anthobranchia and Cladobranchia as in e.g., Papua New Guinea (Table 2; Fig. 10; Gosliner, 1992). For both BNP and Papua New Guinea, the number of Anthobranchia species is twice as much as the Cladobranchia. Anthobranchia mainly feed on sponges although some also feed on bryozoans and tunicates. However, the studies from Ambon and Bali indicate a 3 to 4 time's higher number of Anthobranchia. This might reflect differences in the habitats, but could also be due to collecting priorities in certain habitats. In general, Anthobranchia with the highly diverse Chromodorididae, exhibit higher species diversity than Cladobanchia (Table 2).

No members of the Acteonoidea or Umbraculida were collected during either sampling periods in BNP, whereas at least three acteonoid species were recorded from Bali and one umbraculid from Vietnam. Acteonoidea often burrow in the sand which was not particularly searched through, and Umbraculida are rare and also not recorded in many other studies (Table 2).

Published studies that reveal larger numbers of sea slugs usually based on several subsequent surveys during longer time periods (up to decades). Thus they rather represent a summary of overall species numbers that have been encountered during long time periods, and which actually give no information about any species 


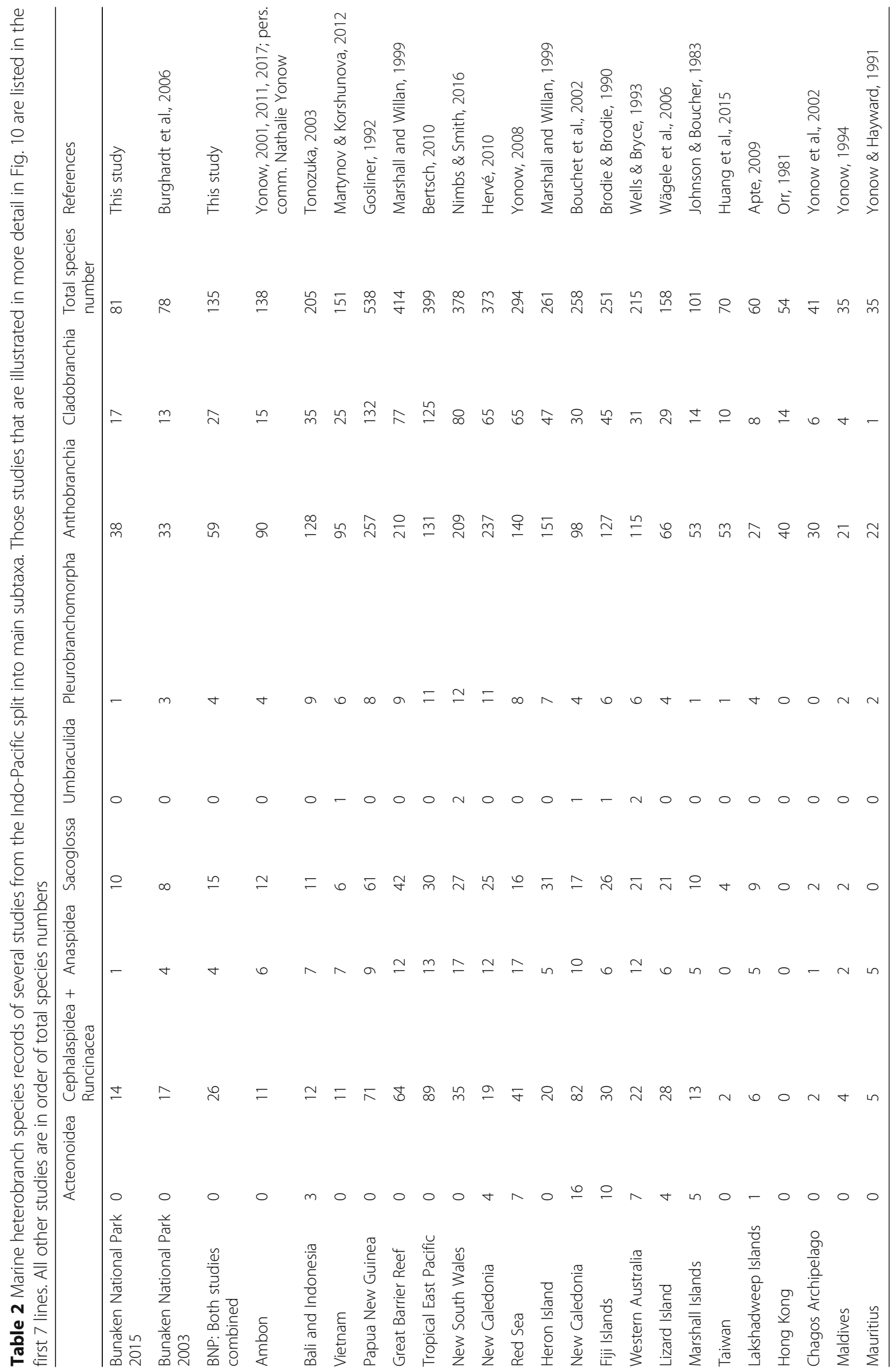


a

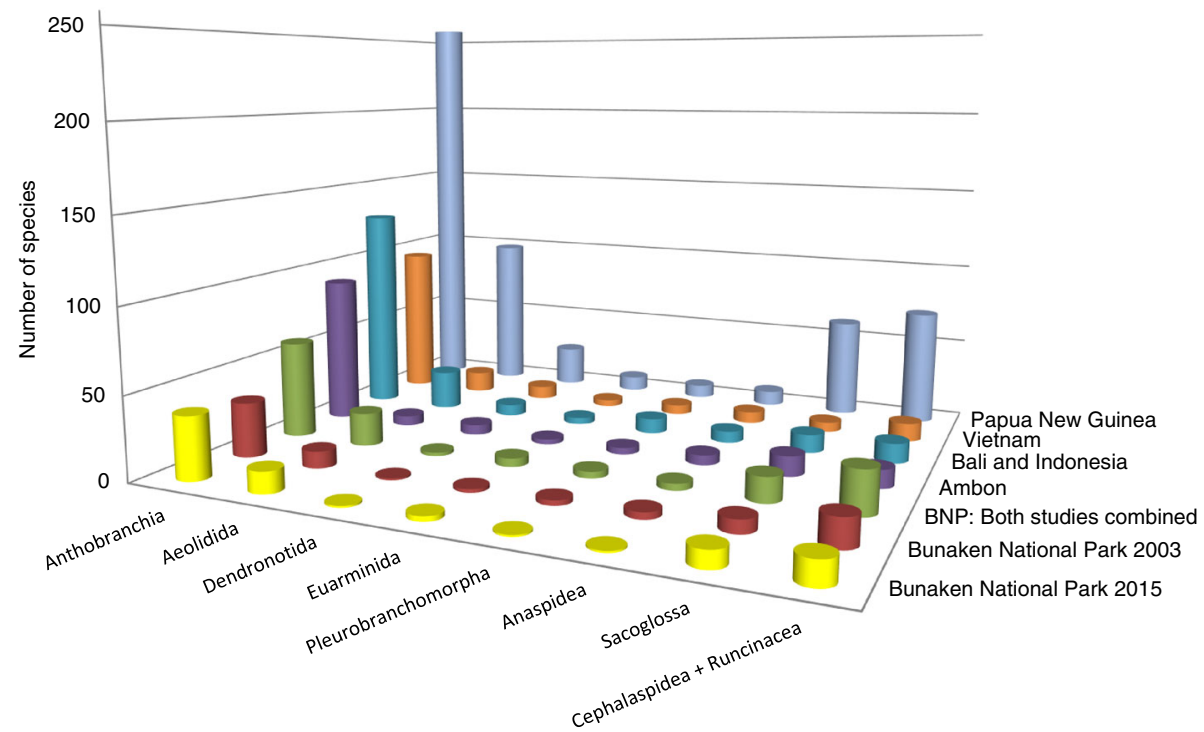

b

\begin{tabular}{|c|c|c|c|c|c|c|c|c|c|c|c|}
\hline & $\begin{array}{l}\frac{\mathbb{d}}{0} \\
\frac{0}{0} \\
\overline{0} \\
\frac{d}{0} \\
\frac{0}{0}\end{array}$ & 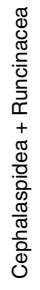 & $\begin{array}{l}\frac{\pi}{8} \\
\frac{0}{0} \\
\frac{0}{0} \\
\frac{\pi}{4}\end{array}$ & 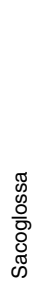 & $\begin{array}{l}\frac{\pi}{0} \\
\frac{0}{5} \\
\widetilde{J} \\
\frac{\pi}{0} \\
\text { है }\end{array}$ & $\begin{array}{l}\frac{\pi}{2} \\
\frac{0}{2} \\
\frac{1}{0} \\
\frac{1}{0} \\
\frac{\pi}{20} \\
\frac{0}{3} \\
\frac{0}{2}\end{array}$ & 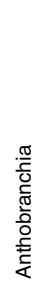 & 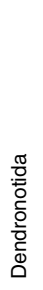 & 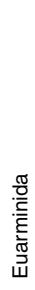 & $\frac{\frac{\pi}{0}}{\frac{0}{\overline{0}}}$ & 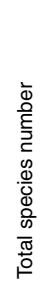 \\
\hline \begin{tabular}{|l|}
$\begin{array}{l}\text { Bunaken National Park } 2015 \\
\text { (this study) }\end{array}$ \\
\end{tabular} & 0 & 14 & 1 & 10 & 0 & 1 & 38 & 1 & 3 & 13 & 81 \\
\hline $\begin{array}{l}\text { Bunaken National Park } 2003 \\
\text { (Burghardt et al., 2006) }\end{array}$ & 0 & 17 & 4 & 8 & 0 & 3 & 33 & 1 & 2 & 10 & 78 \\
\hline $\begin{array}{l}\text { BNP: Both studies combined } \\
\text { (this study) }\end{array}$ & 0 & 26 & 4 & 15 & 0 & 4 & 59 & 2 & 5 & 20 & 135 \\
\hline $\begin{array}{l}\text { Ambon } \\
\text { (Yonow, 2001; 2011; 2017; pers. } \\
\text { comm. Nathalie Yonow) } \\
\end{array}$ & 0 & 11 & 6 & 12 & 0 & 4 & 90 & 6 & 3 & 6 & 138 \\
\hline $\begin{array}{l}\text { Bali and Indonesia } \\
\text { (Tonozuka, 2003) }\end{array}$ & 3 & 12 & 7 & 11 & 0 & 9 & 128 & 7 & 4 & 24 & 205 \\
\hline $\begin{array}{l}\text { Vietnam } \\
\text { (Martynov \& Korshunova, 2012) }\end{array}$ & 0 & 11 & 7 & 6 & 1 & 6 & 95 & 8 & 4 & 13 & 151 \\
\hline $\begin{array}{l}\text { Papua New Guinea } \\
\text { (Gosliner, 1992) }\end{array}$ & 0 & 71 & 9 & 61 & 0 & 8 & 257 & 25 & 9 & 98 & 538 \\
\hline
\end{tabular}

Fig. 10 a Comparison of marine heterobranch subtaxa diversity as recorded in several studies from Indonesia and adjacent regions in the Indo-Pacific. In the graph, order of subtaxa differs from tables for better visualization of data. $\mathbf{b}$ details of the taxa composition and including the very few data on Acteonoidea and Umbraculida

shifts during time of sampling, because no information about recollecting animals is presented. With our two studies in BNP we wanted to reveal a putative change in environmental factors by analyzing differences in species composition. However, this needs first a baseline of overall species diversity in the particular locality with subsequent monitoring of species diversity. This second study is only one of many to follow, to better assess a change of sea slug composition as a result of a changing environment.

\section{Conclusions}

The small overlap of species and observed differences between the two studies from BNP rather illustrates the gap of knowledge on sea slugs from this particular locality, despite sampling at similar times of the year and similar collecting efforts with similarly trained people, than changes of environmental factors in the respective habitats. Many more studies need to be undertaken by well-trained collectors for a better assessment of sea slug diversity in 
Table 3 List of species that were collected and documented during the survey to Bunaken National Park in August 2015. Identifiers are only given for specimens that are depicted in the figures, but could not be assigned to a described species. Five major regions are distinguished according to their separation by larger water areas. Therefore Bunaken Island is also divided into North and South areas. Abbreviations of diving spots in detail see Table 1 and also Fig. 1. Last column indicates, whether the species was collected and documented in Burghardt et al., (2006)

\begin{tabular}{|c|c|c|c|c|c|c|c|c|c|c|c|}
\hline \multirow{2}{*}{$\begin{array}{l}\text { Higher taxon } \\
\text { affiliation }\end{array}$} & \multirow[t]{2}{*}{ Identifier } & \multirow[t]{2}{*}{ Species name } & \multicolumn{5}{|l|}{ Localities } & \multirow{2}{*}{$\begin{array}{l}\text { Depths } \\
\text { in } \mathrm{m}\end{array}$} & \multirow{2}{*}{$\begin{array}{l}\text { Number } \\
\text { of } \\
\text { specimens }\end{array}$} & \multirow{2}{*}{$\begin{array}{l}\text { Size } \\
\text { in } \\
\mathrm{mm}\end{array}$} & \multirow{2}{*}{$\begin{array}{l}\text { Burghardt } \\
\text { et al. } \\
\text { (2006) }\end{array}$} \\
\hline & & & $\begin{array}{l}\text { Bunaken } \\
\text { South }\end{array}$ & $\begin{array}{l}\text { Bunaken } \\
\text { North }\end{array}$ & $\begin{array}{l}\text { Manado } \\
\text { Tua }\end{array}$ & Siladen & Tiwoho & & & & \\
\hline \multicolumn{12}{|l|}{ Cephalaspidea } \\
\hline $\begin{array}{l}\text { Diaphanidae } \\
\text { Odhner, } 1914\end{array}$ & & $\begin{array}{l}\text { Colpodaspis thompsoni } \\
\text { G. H. Brown, } 1979\end{array}$ & $A B$ & PPg, PPi & $\mathrm{Bu}$ & $\mathrm{Si}$ & $\mathrm{Ti}$ & $4-11$ & 15 & $1-6$ & $x$ \\
\hline \multirow[t]{4}{*}{$\begin{array}{l}\text { Aglajidae } \\
\text { Pilsbry, } 1895\end{array}$} & $\begin{array}{l}\text { Agsp15 } \\
\text { Bu-1 }\end{array}$ & Aglajidae spec. & & & & & $\mathrm{Ti}$ & 7 & 1 & 5 & - \\
\hline & & $\begin{array}{l}\text { Chelidonura hirundinina } \\
\text { (Quoy \& Gaimard, 1833) }\end{array}$ & Le2 & & $B L$ & & & $5-6$ & 2 & $\begin{array}{l}15- \\
25\end{array}$ & $x$ \\
\hline & & $\begin{array}{l}\text { Chelidonura amoena } \\
\text { Bergh, } 1905\end{array}$ & $\mathrm{~Pa}$ & & & & & 1 & 1 & 30 & $x$ \\
\hline & & $\begin{array}{l}\text { Odontoglaja guamensis } \\
\text { Rudman, } 1978\end{array}$ & $\mathrm{~Pa}$ & $\begin{array}{l}\mathrm{Ma}, \mathrm{PPg} \\
\mathrm{PPi}\end{array}$ & $B L$ & & $\mathrm{Ti}$ & $3-19$ & 12 & $6-13$ & - \\
\hline \multirow[t]{6}{*}{$\begin{array}{l}\text { Gastropteridae } \\
\text { Swainson, } 1840\end{array}$} & & $\begin{array}{l}\text { Sagaminopteron psychedelicum } \\
\text { Carlson \& Hoff, } 1974\end{array}$ & $\mathrm{Ma}, \mathrm{Pa}$ & PPg, & $B L$ & & & $4-15$ & 7 & $3-8$ & - \\
\hline & & $\begin{array}{l}\text { Siphopteron tigrinum } \\
\text { Gosliner, } 1989\end{array}$ & & $\mathrm{PPi}, \mathrm{MP}$ & & & & $5-6$ & 2 & $5-5$ & $x$ \\
\hline & & $\begin{array}{l}\text { Siphopteron brunneomarginatum } \\
\text { (Carlson \& Hoff, 1974) }\end{array}$ & $\mathrm{Pa}$ & $\begin{array}{l}\text { Ma, PPg, } \\
\mathrm{PPi}\end{array}$ & $B L$ & $\mathrm{Si}$ & & $4-10$ & 5 & $3-5$ & - \\
\hline & & $\begin{array}{l}\text { Siphopteron nigromarginatum } \\
\text { Gosliner, } 1989\end{array}$ & & & $B L$ & & & 5 & 2 & $4-5$ & - \\
\hline & $\begin{array}{l}\text { Sini15Bu- } \\
19+20\end{array}$ & Siphopteron spec. & & PPg & & & & $4-5$ & 2 & 4 & - \\
\hline & & $\begin{array}{l}\text { Siphopteron ladrones } \\
\text { (Carlson \& Hoff, 1974) }\end{array}$ & AS & & & & & 5 & 1 & 4 & - \\
\hline \multirow[t]{2}{*}{$\begin{array}{l}\text { Haminoeidae } \\
\text { Pilsbry, } 1895\end{array}$} & $\begin{array}{l}\text { Hasp15 } \\
\text { Bu-1 }\end{array}$ & $\begin{array}{l}\text { Haminoea spec. } \\
\text { (Haminoea sp. } 2 \text { in Gosliner et al., } \\
\text { 2015: 30) }\end{array}$ & $A B, A S$ & & $B L$ & & & $3-13$ & 4 & $5-8$ & - \\
\hline & $\begin{array}{l}\text { Hasp2_15 } \\
\text { Bu-1 }\end{array}$ & Haminoea spec. & & & & $\mathrm{Si}$ & & 5 & 2 & 4 & - \\
\hline \multicolumn{12}{|l|}{ Runcinacea } \\
\hline $\begin{array}{l}\text { Runcinidae } \\
\text { H. Adams \& A. } \\
\text { Adams, } 1854\end{array}$ & $\begin{array}{l}\text { Rusp15 } \\
\text { Bu-1 }\end{array}$ & Runcina spec. & $A B$ & & & & & 5 & 1 & 2 & - \\
\hline \multicolumn{12}{|l|}{ Anaspidea } \\
\hline $\begin{array}{l}\text { Aplysiidae } \\
\text { Lamarck, } 1809\end{array}$ & & $\begin{array}{l}\text { Stylocheilus striatus } \\
\text { (Quoy \& Gaimard, 1832) }\end{array}$ & CC & & & & & 10 & 1 & 7 & $x$ \\
\hline \multicolumn{12}{|l|}{ Sacoglossa } \\
\hline \multirow[t]{2}{*}{$\begin{array}{l}\text { Oxynoidae } \\
\text { Stoliczka, } 1868\end{array}$} & & $\begin{array}{l}\text { Lobiger viridis } \\
\text { Pease, } 1863\end{array}$ & CC & & & & & 8 & 1 & 8 & - \\
\hline & Lovi15Bu-1 & $\begin{array}{l}\text { Lobiger spec. } \\
\text { (Lobiger sp. } 1 \text { in Gosliner et al., } \\
\text { 2015: 70) }\end{array}$ & CC & & & & & 7 & 1 & 20 & - \\
\hline \multirow[t]{2}{*}{$\begin{array}{l}\text { Caliphyllidae } \\
\text { Tiberi, } 1881\end{array}$} & $\begin{array}{l}\text { Cysp4_ } \\
\text { Bu-1 }\end{array}$ & $\begin{array}{l}\text { Cyerce cf. bourbonica } \\
\text { Yonow, } 2012 \\
\text { (see Gosliner et al., 2015: 71) }\end{array}$ & $A B$ & $M P, P P g$ & & & & $3-10$ & 4 & $4-6$ & - \\
\hline & $\begin{array}{l}\text { Cysp2_15 } \\
\text { Bu-5 }\end{array}$ & Cyerce spec. & $A B$ & MP & & & & $3-7$ & 5 & $4-6$ & - \\
\hline \multirow[t]{2}{*}{$\begin{array}{l}\text { Plakobranchidae } \\
\text { Gray, } 1840\end{array}$} & & $\begin{array}{l}\text { Elysia asbecki } \\
\text { Wägele, Stemmer, } \\
\text { Burghardt \& Händeler, } 2010\end{array}$ & & PPg, PPi & $\mathrm{BL}$ & $\mathrm{Si}$ & $\mathrm{Ti}$ & $4-15$ & 9 & $5-13$ & - \\
\hline & $\begin{array}{l}\text { Elsp19_15 } \\
\text { Bu-2 }\end{array}$ & Elysia spec. & & PPg & & $\mathrm{Si}$ & & $5-9$ & 3 & $5-10$ & - \\
\hline
\end{tabular}


Table 3 List of species that were collected and documented during the survey to Bunaken National Park in August 2015. Identifiers are only given for specimens that are depicted in the figures, but could not be assigned to a described species. Five major regions are distinguished according to their separation by larger water areas. Therefore Bunaken Island is also divided into North and South areas. Abbreviations of diving spots in detail see Table 1 and also Fig. 1. Last column indicates, whether the species was collected and documented in Burghardt et al., (2006) (Continued)

\begin{tabular}{|c|c|c|c|c|c|c|c|c|c|c|c|}
\hline \multirow{2}{*}{$\begin{array}{l}\text { Higher taxon } \\
\text { affiliation }\end{array}$} & \multirow[t]{2}{*}{ Identifier } & \multirow[t]{2}{*}{ Species name } & \multicolumn{5}{|l|}{ Localities } & \multirow{2}{*}{$\begin{array}{l}\text { Depths } \\
\text { in } \mathrm{m}\end{array}$} & \multirow{2}{*}{$\begin{array}{l}\text { Number } \\
\text { of } \\
\text { specimens }\end{array}$} & \multirow{2}{*}{$\begin{array}{l}\text { Size } \\
\text { in } \\
\mathrm{mm}\end{array}$} & \multirow{2}{*}{$\begin{array}{l}\text { Burghardt } \\
\text { et al. } \\
\text { (2006) }\end{array}$} \\
\hline & & & $\begin{array}{l}\text { Bunaken } \\
\text { South }\end{array}$ & $\begin{array}{l}\text { Bunaken } \\
\text { North }\end{array}$ & $\begin{array}{l}\text { Manado } \\
\text { Tua }\end{array}$ & Siladen & Tiwoho & & & & \\
\hline & & $\begin{array}{l}\text { (Elysia sp. } 25 \text { in Gosliner et al., } \\
\text { 2015: 89) }\end{array}$ & & & & & & & & & \\
\hline & & $\begin{array}{l}\text { Thuridilla albopustulosa } \\
\text { Gosliner, } 1995\end{array}$ & & PPg & & & & 6 & 1 & 7 & - \\
\hline & & $\begin{array}{l}\text { Thuridilla flavomaculata } \\
\text { Gosliner, } 1995\end{array}$ & & $\mathrm{Ma}, \mathrm{PPg}$ & & & & $4-7$ & 2 & $\begin{array}{l}10- \\
13\end{array}$ & - \\
\hline & & $\begin{array}{l}\text { Thuridilla gracilis } \\
\text { (Risbec, 1928) }\end{array}$ & $\mathrm{AB}, \mathrm{Pa}$ & PPg, PPi & & $\mathrm{Si}$ & & $3-8$ & 6 & $\begin{array}{l}15- \\
25\end{array}$ & $x$ \\
\hline & & $\begin{array}{l}\text { Thuridilla lineolata } \\
\text { (Bergh, 1905) }\end{array}$ & $\mathrm{Pa}$ & & & $\mathrm{Si}$ & $\mathrm{Ti}$ & $1-9$ & $>50$ & $\begin{array}{l}15- \\
17\end{array}$ & $x$ \\
\hline \multicolumn{12}{|c|}{ Pleurobranchomorpha } \\
\hline $\begin{array}{l}\text { Pleurobranchidae } \\
\text { Gray, } 1827\end{array}$ & & $\begin{array}{l}\text { Pleurobranchus forskalii } \\
\text { Rüppell \& Leuckart, } 1828\end{array}$ & CC & Ma & & $\mathrm{Si}$ & & $4-8$ & 5 & $\begin{array}{l}100- \\
150\end{array}$ & - \\
\hline \multicolumn{12}{|l|}{$\begin{array}{l}\text { Nudibranchia, } \\
\text { Anthobranchia }\end{array}$} \\
\hline $\begin{array}{l}\text { Hexabranchidae } \\
\text { Bergh, } 1891\end{array}$ & & $\begin{array}{l}\text { Hexabranchus sanguineus } \\
\text { (Rüppell \& Leuckart, 1830); egg } \\
\text { mass }\end{array}$ & & PPg & & & & 2 & 2 & - & $x$ \\
\hline $\begin{array}{l}\text { Aegiridae } \\
\text { P. Fischer, } 1883\end{array}$ & & $\begin{array}{l}\text { Notodoris serenae } \\
\text { Gosliner \& Behrens, } 1997\end{array}$ & & & $B L$ & & & 13 & 1 & 100 & - \\
\hline $\begin{array}{l}\text { Goniodorididae } \\
\text { H. Adams \& A. } \\
\text { Adams, } 1854\end{array}$ & & $\begin{array}{l}\text { Trapania euryeia } \\
\text { Gosliner \& Fahay, } 2008\end{array}$ & $A B$ & & & & & 6 & 1 & 7 & - \\
\hline $\begin{array}{l}\text { Gymnodorididae } \\
\text { Odhner, } 1941\end{array}$ & $\begin{array}{l}\text { Gysp1_15 } \\
\text { Bu-2 }\end{array}$ & Gymnodoris spec. & $A B$ & PPg & $B L$ & & & $5-7$ & 3 & $6-13$ & - \\
\hline \multirow{5}{*}{$\begin{array}{l}\text { Polyceridae } \\
\text { Alder \& Hancock, } \\
1845\end{array}$} & & $\begin{array}{l}\text { Nembrotha kubaryana } \\
\text { Bergh, } 1877\end{array}$ & & & & & $\mathrm{Ti}$ & 6 & 1 & 55 & - \\
\hline & & $\begin{array}{l}\text { Nembrotha cristata } \\
\text { Bergh, } 1877\end{array}$ & & $\mathrm{Ma}$ & & $\mathrm{Si}$ & & $4-15$ & 2 & $\begin{array}{l}50- \\
80\end{array}$ & - \\
\hline & & $\begin{array}{l}\text { Kaloplocamus dokte } \\
\text { Vallès \& Gosliner, } 2006\end{array}$ & CC & & & & & 7 & 1 & 10 & - \\
\hline & & $\begin{array}{l}\text { Polycera risbeci } \\
\text { Odhner, } 1941\end{array}$ & & PPi & & & & $7-8$ & 2 & 8 & - \\
\hline & & $\begin{array}{l}\text { Polycera japonica } \\
\text { Baba, } 1949\end{array}$ & & PPi & & & & $7-8$ & 3 & $5-8$ & - \\
\hline \multirow[t]{7}{*}{$\begin{array}{l}\text { Chromodorididae } \\
\text { Bergh, } 1891\end{array}$} & $\begin{array}{l}\text { Cesp2_15 } \\
\text { Bu-3 }\end{array}$ & $\begin{array}{l}\text { Ceratosoma spec. } \\
\text { (Ceratosoma sp. } 1 \text { in Gosliner et } \\
\text { al., 2015: 266) }\end{array}$ & & MP & & & & $5-8$ & 2 & $4-8$ & - \\
\hline & & $\begin{array}{l}\text { Chromodoris cf. boucheti } \\
\text { Rudman, } 1982\end{array}$ & & & & $\mathrm{Si}$ & & 8 & 1 & 20 & - \\
\hline & & $\begin{array}{l}\text { Chromodoris annae } \\
\text { Bergh, } 1877\end{array}$ & $\begin{array}{l}\mathrm{AS}, \mathrm{CC} \\
\mathrm{JW}, \mathrm{Pa}\end{array}$ & PPg & $\mathrm{Bu}, \mathrm{BL}$ & $\mathrm{Si}$ & & $4-23$ & 62 & $6-50$ & $x$ \\
\hline & $\begin{array}{l}\text { Chsp30_15 } \\
\text { Bu-5 }\end{array}$ & $\begin{array}{l}\text { Chromodoris spec. } \\
\text { (Chromodoris sp. } 30 \text { in Debelius \& } \\
\text { Kuiter, 2007: 176) }\end{array}$ & $\begin{array}{l}\text { AS, CC, } \\
\text { JW }\end{array}$ & $\mathrm{Ma}, \mathrm{PPg}$ & $\mathrm{Bu}$ & $\mathrm{Si}$ & & $5-21$ & 23 & $\begin{array}{l}15- \\
40\end{array}$ & - \\
\hline & & $\begin{array}{l}\text { Chromodoris lochi } \\
\text { Rudman, } 1982\end{array}$ & $\mathrm{AS}, \mathrm{Pa}$ & PPg & $B L$ & & & $5-17$ & 9 & $\begin{array}{l}23- \\
50\end{array}$ & $x$ \\
\hline & & $\begin{array}{l}\text { Chromodoris dianae } \\
\text { Gosliner \& Behrens, } 1998\end{array}$ & $\begin{array}{l}\mathrm{AS}, \mathrm{CC} \\
\mathrm{JW}, \mathrm{Pa}\end{array}$ & $\mathrm{Ma}, \mathrm{PPg}$ & $\mathrm{Bu}, \mathrm{BL}$ & $\mathrm{Si}$ & & $4-21$ & 64 & 50 & 0000 \\
\hline & & Chromodoris strigata & & & & $S$ & & 11 & 1 & 25 & $x$ \\
\hline
\end{tabular}


Table 3 List of species that were collected and documented during the survey to Bunaken National Park in August 2015. Identifiers are only given for specimens that are depicted in the figures, but could not be assigned to a described species. Five major regions are distinguished according to their separation by larger water areas. Therefore Bunaken Island is also divided into North and South areas. Abbreviations of diving spots in detail see Table 1 and also Fig. 1. Last column indicates, whether the species was collected and documented in Burghardt et al., (2006) (Continued)

\begin{tabular}{|c|c|c|c|c|c|c|c|c|c|c|c|}
\hline \multirow{2}{*}{$\begin{array}{l}\text { Higher taxon } \\
\text { affiliation }\end{array}$} & \multirow[t]{2}{*}{ Identifier } & \multirow[t]{2}{*}{ Species name } & \multicolumn{5}{|l|}{ Localities } & \multirow{2}{*}{$\begin{array}{l}\text { Depths } \\
\text { in } \mathrm{m}\end{array}$} & \multirow{2}{*}{$\begin{array}{l}\text { Number } \\
\text { of } \\
\text { specimens }\end{array}$} & \multirow{2}{*}{$\begin{array}{l}\text { Size } \\
\text { in } \\
\mathrm{mm}\end{array}$} & \multirow{2}{*}{$\begin{array}{l}\text { Burghardt } \\
\text { et al. } \\
\text { (2006) }\end{array}$} \\
\hline & & & $\begin{array}{l}\text { Bunaken } \\
\text { South }\end{array}$ & $\begin{array}{l}\text { Bunaken } \\
\text { North }\end{array}$ & $\begin{array}{l}\text { Manado } \\
\text { Tua }\end{array}$ & Siladen & Tiwoho & & & & \\
\hline & & $\begin{array}{l}\text { Rudman, } 1982 \\
\text { (first identified as } \\
\text { C. michaeli) }\end{array}$ & & & & & & & & & \\
\hline & & $\begin{array}{l}\text { Chromodoris willani } \\
\text { Rudman, } 1982\end{array}$ & $\begin{array}{l}\mathrm{AS}, \mathrm{CC}, \\
\mathrm{Pa}\end{array}$ & & $B L$ & $\mathrm{Si}$ & & $7-21$ & 36 & $\begin{array}{l}20- \\
70\end{array}$ & $x$ \\
\hline & & $\begin{array}{l}\text { Goniobranchus } \\
\text { geometricus } \\
\text { (Risbec, 1928) }\end{array}$ & & PPg & & & $\mathrm{Ti}$ & $4-8$ & 3 & $\begin{array}{l}10- \\
40\end{array}$ & $x$ \\
\hline & & $\begin{array}{l}\text { Goniobranchus reticulatus } \\
\text { (Quoy \& Gaimard, 1832) }\end{array}$ & & & TK & & & 15 & 1 & 75 & - \\
\hline & & $\begin{array}{l}\text { Doriprismatica stellata } \\
\text { (Rudman, 1986) }\end{array}$ & $\mathrm{CC}, \mathrm{Pa}$ & PPg & & & & $4-21$ & 5 & $\begin{array}{l}50- \\
60\end{array}$ & - \\
\hline & & $\begin{array}{l}\text { Glossodoris cincta } \\
\text { (Bergh, 1888) }\end{array}$ & & & & & $\mathrm{Ti}$ & 6 & 1 & 30 & - \\
\hline & & $\begin{array}{l}\text { Hypselodoris maculosa } \\
\text { (Pease, 1871) }\end{array}$ & $A B$ & & & & $\mathrm{Ti}$ & $4-6$ & 2 & $4-13$ & - \\
\hline & & $\begin{array}{l}\text { Thorunna australis } \\
\text { (Risbec, 1928) }\end{array}$ & $A B$ & & & & $\mathrm{Ti}$ & 2 & 1 & 17 & - \\
\hline \multirow[t]{4}{*}{$\begin{array}{l}\text { Discodorididae } \\
\text { Bergh, } 1891\end{array}$} & & $\begin{array}{l}\text { Taringa halgerda } \\
\text { Gosliner \& Behrens, } 1998\end{array}$ & $A B$ & & & & $\mathrm{Ti}$ & 6 & 1 & 10 & - \\
\hline & & $\begin{array}{l}\text { Halgerda carlsoni } \\
\text { Rudman, } 1978\end{array}$ & & & $B L$ & & & 5 & 1 & 15 & - \\
\hline & & $\begin{array}{l}\text { Halgerda tessellata } \\
\text { (Bergh, 1880) }\end{array}$ & & & & $\mathrm{Si}$ & & 5 & 1 & 8 & - \\
\hline & $\begin{array}{l}\text { Halsp4_15 } \\
\text { Bu-1 }\end{array}$ & $\begin{array}{l}\text { Rostanga spec. } \\
\text { (Rostanga sp. } 9 \text { in } \\
\text { Gosliner et al., 2015: 200) }\end{array}$ & & & $B L$ & & & 5,8 & 1 & 3 & - \\
\hline \multirow{2}{*}{$\begin{array}{l}\text { Dendrodorididae } \\
\text { O'Donoghue, } \\
1924\end{array}$} & & $\begin{array}{l}\text { Dendrodoris albobrunnea } \\
\text { Allan, } 1933\end{array}$ & $\mathrm{~Pa}$ & & & & & 4 & 1 & 40 & - \\
\hline & & $\begin{array}{l}\text { Dendrodoris nigra } \\
\text { (Stimpson, 1855) }\end{array}$ & $\mathrm{Pa}$ & & & & & 4 & 1 & 30 & - \\
\hline \multirow[t]{9}{*}{$\begin{array}{l}\text { Phyllidiidae } \\
\text { Rafinesque, } 1814\end{array}$} & & $\begin{array}{l}\text { Phyllidia coelestis } \\
\text { Bergh, } 1905\end{array}$ & $A B, C C$ & $\begin{array}{l}\mathrm{Ma}, \mathrm{PPi}_{1} \\
\mathrm{PPg}\end{array}$ & $B L$ & & $\mathrm{Ti}$ & $2-15$ & 20 & $\begin{array}{l}10- \\
40\end{array}$ & $x$ \\
\hline & & $\begin{array}{l}\text { Phyllidia elegans } \\
\text { Bergh, } 1869\end{array}$ & $\begin{array}{l}A B, A S \\
J W\end{array}$ & $\mathrm{Ma}, \mathrm{PPg}$ & & $\mathrm{Si}$ & & $2-19$ & 13 & $\begin{array}{l}10- \\
40\end{array}$ & $x$ \\
\hline & & $\begin{array}{l}\text { Phyllidia ocellata } \\
\text { Cuvier, } 1804\end{array}$ & & & & & $\mathrm{Ti}$ & 5 & 1 & 30 & $x$ \\
\hline & & $\begin{array}{l}\text { Phyllidia varicosa } \\
\text { Lamarck, } 1801\end{array}$ & $\begin{array}{l}\mathrm{AS}, \mathrm{CC} \\
\mathrm{Pa}\end{array}$ & PPg & & & & $4-21$ & 10 & $\begin{array}{l}30- \\
80\end{array}$ & $x$ \\
\hline & & $\begin{array}{l}\text { Phyllidiella pustulosa } \\
\text { (Cuvier, 1804) }\end{array}$ & $\begin{array}{l}\mathrm{AS}, \mathrm{CC} \\
\mathrm{JW}, \mathrm{Pa}\end{array}$ & $\mathrm{Ma}, \mathrm{PPg}$ & $\mathrm{Bu}, \mathrm{BL}$ & $\mathrm{Si}$ & $\mathrm{Ti}$ & 5-19 & 44 & $\begin{array}{l}13- \\
80\end{array}$ & $x$ \\
\hline & & $\begin{array}{l}\text { Phyllidiella annulata } \\
\text { (Gray, 1853) }\end{array}$ & AS & PPg & $B L$ & & & $11-13$ & 3 & 15 & - \\
\hline & & $\begin{array}{l}\text { Phyllidiopsis xishaensis } \\
\text { (Lin, 1983) }\end{array}$ & AS & & & & & 15 & 1 & 13 & - \\
\hline & & $\begin{array}{l}\text { Phyllidiopsis pipeki } \\
\text { Brunckhorst, } 1993\end{array}$ & $A S, C C$ & $\mathrm{Ma}$ & & & & $14-15$ & 3 & $\begin{array}{l}25- \\
40\end{array}$ & - \\
\hline & & $\begin{array}{l}\text { Phyllidiopsis sphingis } \\
\text { Brunckhorst, } 1993\end{array}$ & & & $\mathrm{Bu}$ & & & 19 & 1 & 5 & - \\
\hline
\end{tabular}


Table 3 List of species that were collected and documented during the survey to Bunaken National Park in August 2015. Identifiers are only given for specimens that are depicted in the figures, but could not be assigned to a described species. Five major regions are distinguished according to their separation by larger water areas. Therefore Bunaken Island is also divided into North and South areas. Abbreviations of diving spots in detail see Table 1 and also Fig. 1. Last column indicates, whether the species was collected and documented in Burghardt et al., (2006) (Continued)

\begin{tabular}{|c|c|c|c|c|c|c|c|c|c|c|c|}
\hline \multirow{2}{*}{$\begin{array}{l}\text { Higher taxon } \\
\text { affiliation }\end{array}$} & \multirow[t]{2}{*}{ Identifier } & \multirow[t]{2}{*}{ Species name } & \multicolumn{5}{|l|}{ Localities } & \multirow{2}{*}{$\begin{array}{l}\text { Depths } \\
\text { in } \mathrm{m}\end{array}$} & \multirow{2}{*}{$\begin{array}{l}\text { Number } \\
\text { of } \\
\text { specimens }\end{array}$} & \multirow{2}{*}{$\begin{array}{l}\text { Size } \\
\text { in } \\
\mathrm{mm}\end{array}$} & \multirow{2}{*}{$\begin{array}{l}\text { Burghardt } \\
\text { et al. } \\
\text { (2006) }\end{array}$} \\
\hline & & & $\begin{array}{l}\text { Bunaken } \\
\text { South }\end{array}$ & $\begin{array}{l}\text { Bunaken } \\
\text { North }\end{array}$ & $\begin{array}{l}\text { Manado } \\
\text { Tua }\end{array}$ & Siladen & Tiwoho & & & & \\
\hline \multicolumn{12}{|l|}{ Dendronotida } \\
\hline $\begin{array}{l}\text { Dotidae } \\
\text { Gray, } 1853\end{array}$ & $\begin{array}{l}\text { Dotosp15 } \\
\text { Bu-1 }\end{array}$ & Kabeiro spec. & & & $B L$ & & & 19 & 1 & 5 & - \\
\hline \multicolumn{12}{|l|}{ Euarminida } \\
\hline \multirow{2}{*}{$\begin{array}{l}\text { Arminidae } \\
\text { Iredale \& } \\
\text { O'Donoghue,1923 }\end{array}$} & $\begin{array}{l}\text { Dest15 } \\
\text { Bu-1 }\end{array}$ & Dermatobranchus spec. & & & $B L$ & & & 7 & 1 & 30 & - \\
\hline & & $\begin{array}{l}\text { Dermatobranchus fasciatus } \\
\text { Gosliner \& Fahey, } 2011\end{array}$ & & PPg & & & & 7 & 1 & 12 & - \\
\hline \multicolumn{12}{|l|}{ Aeolidida } \\
\hline \multirow[t]{3}{*}{$\begin{array}{l}\text { Flabellinidae } \\
\text { Bergh, } 1889\end{array}$} & & $\begin{array}{l}\text { Flabellina exoptata } \\
\text { Gosliner \& Willan, } 1991\end{array}$ & $\mathrm{~Pa}$ & PPg & & $\mathrm{Si}$ & & $5-8$ & 5 & 20 & $x$ \\
\hline & & $\begin{array}{l}\text { Flabellina bicolor } \\
\text { (Kelaart, 1858) }\end{array}$ & & & & $\mathrm{Si}$ & $\mathrm{Ti}$ & $4-8$ & 3 & $8-13$ & - \\
\hline & & $\begin{array}{l}\text { Flabellina rubrolineata } \\
\text { (O'Donoghue, 1929) }\end{array}$ & $A B$ & & & & & 6 & 1 & 30 & - \\
\hline \multirow[t]{10}{*}{$\begin{array}{l}\text { Facelinidae } \\
\text { Bergh, } 1889\end{array}$} & & $\begin{array}{l}\text { Caloria indica } \\
\text { (Bergh, 1896) }\end{array}$ & $J W$ & & $\mathrm{Bu}$ & $\mathrm{Si}$ & $\mathrm{Ti}$ & $3-6$ & 6 & $7-40$ & - \\
\hline & $\begin{array}{l}\text { Casp15 } \\
\text { Bu-1 }\end{array}$ & $\begin{array}{l}\text { Caloria spec. } \\
\text { (Caloria sp. } 1 \text { in Gosliner et al., } \\
\text { 2015: 362) }\end{array}$ & & PPg & & & & 17 & 1 & 5 & - \\
\hline & $\begin{array}{l}\text { Nosp2_15 } \\
\text { Bu-1 }\end{array}$ & Noumeaella spec. & CC & $\mathrm{Ma}, \mathrm{MP}$ & & & & $4-12$ & 7 & $\begin{array}{l}12- \\
30\end{array}$ & - \\
\hline & & $\begin{array}{l}\text { Phyllodesmium poindimiei } \\
\text { (Risbec, 1928) }\end{array}$ & JW & PPg & & & & 17 & 2 & $4-8$ & - \\
\hline & & $\begin{array}{l}\text { Phyllodesmium briareum } \\
\text { (Bergh, 1896) }\end{array}$ & & & $B L$ & & $\mathrm{Ti}$ & $2-7$ & Ca 50 & $\begin{array}{l}10- \\
30\end{array}$ & $x$ \\
\hline & & $\begin{array}{l}\text { Facelina rhodopos } \\
\text { Yonow, } 2000\end{array}$ & & & TK & & & 15 & 1 & 30 & - \\
\hline & & $\begin{array}{l}\text { Favorinus mirabilis } \\
\text { Baba, } 1955\end{array}$ & & Ma & & & & 23 & 1 & 12 & - \\
\hline & & $\begin{array}{l}\text { Favorinus japonicus } \\
\text { Baba, } 1949\end{array}$ & $A B$ & & & $\mathrm{Si}$ & & $5-10$ & 4 & $5-8$ & - \\
\hline & & $\begin{array}{l}\text { Favorinus tsuruganus } \\
\text { Baba \& Abe, } 1964\end{array}$ & $A B, A S$ & $\begin{array}{l}\mathrm{Ma}, \mathrm{PPi} \\
\mathrm{PPg}\end{array}$ & & & & $6-23$ & 7 & $8-20$ & - \\
\hline & & $\begin{array}{l}\text { Pteraeolidia semperi } \\
\text { (Bergh, 1870) }\end{array}$ & $\mathrm{AS}, \mathrm{Pa}$ & PPi, PPg & $\mathrm{Bu}, \mathrm{BL}$ & $\mathrm{Si}$ & $\mathrm{Ti}$ & $4-15$ & 20 & $6-50$ & $\begin{array}{l}X \text { (as } P \text {. } \\
\text { ianthina) }\end{array}$ \\
\hline \multicolumn{12}{|c|}{ [unassigned] Cladobranchia } \\
\hline $\begin{array}{l}\text { Proctonotidae } \\
\text { Gray, } 1853\end{array}$ & $\begin{array}{l}\text { Cysp15 } \\
\text { Bu-1 }\end{array}$ & $\begin{array}{l}\text { Janolus spec. } \\
\text { (Janolus sp. } 11 \text { in } \\
\text { Gosliner et al., 2015: 308) }\end{array}$ & $\mathrm{CC}$ & & & & & 7 & 1 & 10 & - \\
\hline
\end{tabular}


BNP. Future investigations during other seasons are also necessary to obtain more information about seasonality of marine heterobranchs. However, to assess changes in the environment due to local or global stressors, a higher number of surveys with more accurate description of time lines are necessary to identify shifts in species communities and diversity. This study presented here with detailed information on localities and habitat structure is the beginning of such a time line with more surveys to follow in order to monitor any changes in the coral reefs in BNP.

\section{Acknowledgements}

We wish to thank the staff at Panorama on Bunaken Island and Victoria Moris (Freiburg, Germany), who supported our collecting and documentation. We also wish to thank Elise Laetz (Bonn, Germany) for improving English language in this ms. Two reviewers helped with many valuable comments and thus improved the manuscript considerably. Nathalie Yonow (Swansea, Wales) kindly provided unpublished data on Ambon material and also gave valuable comments to our manuscript. We are very grateful to Markus Lasut and Grevo Gerung (Faculty of Fisheries and Marine Sciences, Sam Ratulangi University, Manado) for support and helping in the ABS paper work. The material was legally collected with permits for the Bunaken National Park to F. Kaligis and T.F. Schäberle. No material collected during this study is listed in IUCN or CITES. Addendum: Fontje Kaligis passed away on September 19, 2017. Here we want to express our gratitude to our colleague who considerably contributed to the success of this study in his home country.

\section{Ethics approval and consent to participated}

Not applicable

\section{Funding}

This study was funded by the Federal Ministry of Education and Research (BMBF) in the frame of the "Biodiversity and Health - from biodiscovery to biomedical innovation" program (IndoBio project, grants 16GW0117K and 16GW0118) to H. Wägele, G. M. König and T. F. Schäberle and partly by the DAAD to F. Kaligis.

\section{Availability of data and materials}

The material is partly available from HW and partly from FK and RB. Some material is used for further studies within the project funded by the BMBF. Metadata of each individual will be finally documented in the database BiodiversityCollection (Diversity Workbench). Pictures are available from HW with copyright from ZFMK.

\section{Authors' contributions}

All authors except JHE were involved in collecting the animals. HW wrote the manuscript. FK, RB, JHE, TFS and GMK contributed to the manuscript. FJ, HW, and JHE designed the figures. All authors read and approved the final manuscript.

\section{Consent for publication \\ Not applicable}

\section{Competing interests}

The authors declare that they have no competing interests.

\section{Publisher's Note}

Springer Nature remains neutral with regard to jurisdictional claims in published maps and institutional affiliations.

\section{Author details}

"Faculty of Fisheries and Marine Science, Sam Ratulangi University, Manado, Indonesia. ${ }^{2}$ Centre of Molecular Biodiversity, Zoological Research Museum Alexander Koenig, Bonn, Germany. ${ }^{3}$ Panorama Resort and Diving Centre, Manado, Bunaken Island, Indonesia. ${ }^{4}$ Institute for Insect Biotechnology,
Justus-Liebig-University of Giessen, Giessen, Germany. ${ }^{5}$ Institute for Pharmaceutical Biology, University of Bonn, Bonn, Germany.

Received: 23 August 2017 Accepted: 15 January 2018

Published online: 06 February 2018

\section{References}

Allen GG, Erdmann MV. Reef fishes of the east indies. Vol I-III. Tropical Reef Research: Perth; 2012.

Apte D. Opisthobranch fauna of Lakshadweep Islands, India, with 52 new records to Lakshadweep and 40 new records to India: part 1. J Bombay Nat Hist Soc. 2009;106:162-75.

Bergh R. Reisen im Archipel der Philippinen von Dr. C. Semper. Zweiter Theil. Wissenschaftliche Resultate. 1889;Bd. 2, Heft 16:815-872.

Bertsch H. Biogeography of northeast Pacific opisthobranchs: comparative faunal province studies between point conception, California, USA, and Punta Aguja, Piura, Perú. Persp Malacol Mexicana. 2010;13:219-59.

Bouchet P, Lozouet P, Maestrati P, Heros V. Assessing the magnitude of species richness in tropical marine environments: exceptionally high numbers of molluscs at a New Caledonia site. Biol J Linn Soc. 2002;75:421-36.

Brodie GD, Brodie JE. A checklist of the opisthobranch molluscs of Fiji. J Malacol Soc Austr. 1990;11:53-63.

Brunckhorst DJ. The systematics and phylogeny of phyllidiid nudibranchs (Doridoidea). Rec Austr Mus. 1993;16:1-107.

Burghardt I, Carvalho R, Eheberg D, Gerung G, Kaligis F, Mamangkey G, Schroedl M, Schwabe E, Vonnemann V, Waegele H. Molluscan diversity at Bunaken National Park, Sulawesi. J Zool Soc Wallacea. 2006;2:29-43.

De'ath G, Fabricius KE, Sweatman H, Puotinen M. The 27-year decline of coral cover on the great barrier reef and its causes. Proc Nat Acad Sci. 2012;109: 17995-9.

Debelius H, Kuiter RH. Nacktschnecken der Weltmeere. Frankfurt: IKANUnterwasserarchiv; 2007.

Dharma B. Recent \& fossil Indonesian shells. Hackenheim: ConchBooks; 2005.

Fabricius $K$, Alderslade P. Soft corals and sea fans - a comprehensive guide to the tropical shallow-water genera of the central-West-Pacific, the Indian Ocean and the Red Sea. Australian Institute of Marine Science: Townsville; 2001.

Gosliner TM. Biodiversity of tropical opisthobranch gastropod faunas. Proc Seventh Int Cor Reef Symp, Guam. 1992;2:702-9.

Gosliner TM, Behrens DW, Valdés Á. Indo-Pacific Nudibranchs and sea slugs: a field guide to the World's most diverse fauna. San Francisco: Sea Challengers; 2008.

Gosliner TM, Behrens DW, Williams GC. Coral reef animals of the indo-Pacific: animal life from Africa to Hawaii exclusive of the vertebrates. San Francisco: Sea Challengers; 1996.

Gosliner TM, Valdés Á, Behrens DW. Nudibranch and sea slug identification indo-Pacific. Jacksonville: New World Publications; 2015.

Hervé J-F. Guide des nudibranches de Nouvelle-Calédonie et autres opisthobranches. Nouméa: Editions Catherine Ledru; 2010.

Hoeksema BW, Matthews JL. Contrasting bleaching patterns in mushroom coral assemblages at Koh Tao, gulf of Thailand. Coral Reefs. 2011;30:95.

Huang H-D, Tsai Y-C, Chen C-K, Hung H-T, Chen J-C, Lin H, Lee K-S. Diverse opisthobranchs and polyclad flatworms in Houwan, Kenting National Park, southern Taiwan. Coll \& Res. 2015;28:55-65.

Hurtado AQ, Gerung GS, Yasir S, Critchley AT. Cultivation of tropical seaweeds in the BIMP-EAGA region. J Appl Phycol. 2014;26:707-18.

Johnson S, Boucher LM. Notes on some Opisthobranchia (Mollusca: Gastropoda) from the Marshall Islands, including 57 new records. Pac Sci. 1983;37:251-91.

Kholil NS, Sulistyadi Y. The best strategy for ensuring sustainability of Bunaken National Park, North Sulawesi Indonesia. J Tour Hosp Managem. 2017;5:78-85.

Korshunova T, Martynov A, Bakken T, Evertsen J, Fletcher K, Mudianta IW, Saito H, Lundin K, Schrödl M, Picton B. Polyphyly of the traditional family Flabellinidae affects a major group of Nudibranchia: aeolidacean taxonomic reassessment with descriptions of several new families, genera, and species (Mollusca, Gastropoda). ZooKeys. 2017:717:1-139.

Maabuat PV, Sampekalo J, Simbala HGI. Keanekaragaman lamun di Pesisir Pantai Molas, kecamatan Bunaken Kota Manado (Biodiversity of Seegrass in Molas Seashore in Bunaken Subdistrict, Manado). Bioslogos. 2012;2:20-7.

Marshall JG, Willan RC. Nudibranchs of Heron Island, great barrier reef. Leiden: Backhuys Publishers; 1999. 
Martynov AV, Korshunova TA. Opisthobranch molluscs of Vietnam (Gastropoda: Opisthobranchia). In: Britayev TA, Pavlov DS, editors. Benthic fauna of the bay of Nhatrang, southern Vietnam, vol. 2. Moscow: KMK Scientific Press; 2012. p. 142-257.

McClanahan TR, Muthiga NA. Community change and evidence for variable warm-water temperature adaptation of corals in northern male atoll, Maldives. Mar Pollut Bull. 2014;80:107-13.

Nimbs MJ, Larkin M, Davis TR, Harasti D, Willan RC, Smith DA. Southern range extensions for twelve heterobranch sea slugs (Gastropoda: Heterobranchia) on the eastern coast of Australia. Mar Biodivers Rec. 2016;9:27.

Nimbs MJ, Smith DA. An illustrated inventory of the sea slugs of new South Wales, Australia (Gastropoda: Heterobranchia). R Soc Vic. 2016;128:44-113.

Ong E, Hallas JM, Gosliner TM. Like a bat out of heaven: the phylogeny and diversity of the bat-winged slugs (Heterobranchia: Gastropteridae). Zool J Linnean Soc. 2017:180:755-89.

Orr J. Hong Kong nudibranchs. Urban Council: Hong Kong; 1981.

Pangemanan A, Maryunani LH, Polii B. Economic analysis of Bunaken Nasional Park ecotourism area based on the carrying capacity and visitation level. Asian Trans Basic Appl Sci. 2012;2:34-40.

Ruga L, Langoy M, Papu A, Kolondam B. Identifikasi zooplankton di Perairan Pulau Bunaken Manado. (zooplankton identification in Bunaken Island waters Manado). Jurnal MIPA Unsrat Online. 2014;3:84-6.

Sea Slug Forum. http://www.seaslugforum.net/. Accessed 10 Nov 2017.

Setiawan F, Santoso G, Handoyo EW, Setiyawati T, Uyun YS. Kajian Keefektifan Zonasi Berdasarkan Komunitas Ikan Karang di Taman Nasional Bunaken, Sulawesi Utara. (Reef Fishes biodiversity in marine sanctuary at Minahasa Utara District, North Sulawesi). Jurnal IImu Teknologi Kelautan Tropics. 2013;8: $57-71$.

Shipman C, Gosliner T. Molecular and morphological systematics of Doto Oken, 1851 (Gastropoda: Heterobranchia), with descriptions of five new species and a new genus. Zootaxa. 2015;3973:57-101.

Stoffel BEMW, van der Meij SET, Hoeksema BW, van Alphen J, van Alen T, MeyersMuñoz MA, de Voogd NJ, Tuti Y, van der Velde G. Phylogenetic relationships within the Phyllidiidae (Opisthobranchia, Nudibranchia). Zookeys. 2016;605:1-35.

Tonozuka T. Opisthobranchs of Bali and Indonesia. Tokyo: Hankyu Communications Co. Ltd.; 2003.

Triebel D, Hagedorn G, Jablonski S, Rambold G. Diversity Workbench - A virtual research environment for building and accessing biodiversity and environmental data. http://www.diversityworkbench.net/. Accessed 10 Nov 2017

Wägele H, Burghardt I, Anthes N, Evertsen J, Klussmann-Kolb A, Brodie G. Species diversity of opisthobranch molluscs on Lizard Island, great barrier reef, Australia. Rec West Austr Mus Suppl. 2006;69:33-59.

Wells FE, Bryce CW. Sea slugs of western Australia. Perth: Western Australian Museum; 1993.

WoRMS Editorial Board. World Register of Marine Species. http://www. marinespecies.org/. Accessed 10 Nov 2017.

Yonow N. Opisthobranchs from the Maldive Islands, including descriptions of seven new species (Mollusca: Gastropoda). Rev Franç d'Aquar Herpét. 1994; 20(4):97-130.

Yonow N. Results of the Rumphius biohistorical expedition to Ambon (1990). Part 11. Doridacea of the families Chromodorididae and Hexabranchidae (Mollusca, Gastropoda, Opisthobranchia, Nudibranchia), including additional Moluccan material. Zool Meded. 2001;75:1-50.

Yonow N. Sea slugs of the Red Sea. Sofia: Pensoft Publishers; 2008.

Yonow N. Results of the Rumphius biohistorical expedition to Ambon (1990). Part 15. The suborder Doridina (Mollusca, Gastropoda, Opisthobranchia, Nudibranchia). Zool. Meded. 2011;85(17):905-56.

Yonow N. Opisthobranchs from the western Indian Ocean, with descriptions of two new species and ten new records (Mollusca, Gastropoda). ZooKeys. 2012;197:1-129.

Yonow N. Results of the Rumphius biohistorical expedition to Ambon (1990). Part 16. The Nudibranchia - Dendronotina, Arminina, Aeolidina, and Doridina (Mollusca: Gastropoda: Heterobranchia). Arch Molluskenkd. 2017;146(1):135-72.

Yonow N, Anderson RA, Buttress SG. Opisthobranch molluscs from the Chagos archipelago, Central Indian Ocean. J Nat Hist. 2002;36:831-82.

Yonow N, Hayward PJ. Opisthobranches de l'lle Maurice, avec la description de deux espèces nouvelles (Mollusca: Opisthobranchia). Rev Franç d'Aquar Herpét. 1991;18(1):1-30.

\section{Submit your next manuscript to BioMed Central and we will help you at every step:}

- We accept pre-submission inquiries

- Our selector tool helps you to find the most relevant journal

- We provide round the clock customer support

- Convenient online submission

- Thorough peer review

- Inclusion in PubMed and all major indexing services

- Maximum visibility for your research

Submit your manuscript at www.biomedcentral.com/submit
C Biomed Central 